\title{
Turhal-Pazar-Zile (Tokat) Yöresinin Üst Mesozoyik Stratigrafisi
}

\author{
The Upper Mesozoic Stratigraphy of Turhal, Pazar, Zile (Tokat) Region
}

\author{
Hülya GÜRELI YOLCUBAL ${ }^{1}$, Mehmet AKYAZI ${ }^{2}$, T. Fikret SEZEN ${ }^{2}$, Özlem TOPRAK ${ }^{3}$, M.Yasin \\ CANBOLAT $^{2}$, Filiz KOÇAK ${ }^{2}$, Ayșegül ÖZKAN ${ }^{4}$ \\ ${ }^{1}$ Cumhuriyet Üniversitesi, Fen Bilimleri Enstitüsü, 58140 Sivas \\ ${ }^{2}$ Cumhuriyet Üniversitesi, Jeoloji Mühendisliği Bölümü, 58140 Sivas \\ ${ }^{3}$ Gaziosmanpaşa Üniversitesi, Teknik Bilimler MYO, Taşlıçiftlik Yerleşkesi, 60100 Tokat \\ ${ }^{4}$ Sivas Pansiyon, Atatürk Caddesi Kepçeli Mevki,58000 Sivas
}

ÖZ: Orta Pontid Tektonik Kuşağında, Anatolid-Pontid Tektonik Kuşağı sınırındaki, Tokat ilinin kuzeybatısında yer alan inceleme alanındaki stratigrafik birimler incelendiğinde tüm Pontid Tektonik Kuşağında olduğu gibi bir temel örtü ayırdımının varlığı saptanmıştır. Temel kayaçları üzerinde uyumsuzlukla yer alan örtü kayaçlarından özellikle çeșitlilik ve fosil içeriği bakımından oldukça ilgi çekici olan Üst Mesozoyik yaşlı örtü birimlerine detay yaş verilerek yöre stratigrafisi kurgulanmış ve çalışma alanının, jeolojik ve stratigrafik konumuna yönelik bulgular saptanmıştır.

Anahtar kelimeler: Paleontoloji, Pazar, stratigrafi, Tokat, Turhal, Üst Mesozoyik, Zile.

ABSTRACT: The presences of base-cover separation are established as all Pontid Tectonic Belt when stratigraphic units are investigated in the studied area that is located at the northwest of Tokat city. Upper Mesozoic cover units are one of cover units located uncormably on base units and are interesting in terms of fossil content and diversity. In this study, these units are dated as detail and stratigraphy of region is constructed according to these ages. In addition, data of the geologic and stratigraphic positions of study area are observed.

Key Words: Paleontology, Pazar, Stratigraphy, Tokat, Turhal, Upper Mesozoic, Zile.

\section{GİRIŞ}

İnceleme alanı, Karadeniz Bölgesinde, Tokat iline bağlı Zile, Turhal ve güneydeki Pazar İlçesi kuzeyinde yeralmaktadır. 1/25.000 ölçekli Çorum H 35-b3-b4 paftalarının güney yarısı ile Çorum H35-c1-c2 paftalarının kuzey yarısında ki yaklaşı $100 \mathrm{~km}^{2}$ lik bir alanda ve Çorum $\mathrm{H}$ 36a1-a2 paftalarıla, Çorum H36-a3-a4 paftalarının kuzey yarısında ki $240 \mathrm{~km}^{2}$ lik bir alanı kapsar.

Zile, Turhal, Pazar (Tokat) yöresindeki örtü birimlerinin paleontolojisi ve stratigrafisi konulu bu çalışma kapsamında ağırlıklı olarak Üst Mesozoyik 
yaşlı birimler olmak üzere özellikle de denizel olanlarının ayrıntılı paleontolojisinin yapılması ve bölgenin stratigrafisinin ayrintılı olarak ortaya konulması amaçlanmaktadır. Pliyosen'de tamamen karasallaşan bölgedeki istifin jeolojisinin ve ağırlıklı olarak Jura-Kretase yaşlı birimlerin stratigrafisinin ayrıntılı olarak tanımlanmasına yönelik yeni veriler elde etmek ve/veya bölgede daha önce yapılmış olan çalışmalara bir katma değer yaratmak bu çalışmanın birincil hedefini oluşturmaktadır.

Bölgede daha önce yapılan çalışmalarda coğrafik olarak birbirlerine oldukça yakın olan bölgelerdeki birimler aynı stratigrafik düzeyde olmalarına karşın değişik formasyon adlamaları yapılmış olduğu görülmektedir. Yapılan bu çalışmada seçilen bölge ve yakın yörelerde tanımlanmış olan aynı kronostratigrafik düzeyde olan birimlerin detay paleontolojisi ve stratigrafisi yapılarak bu birimlerin aynı litostratigrafik ad altında birleştirilebilmesi konusuna yönelik olarak lito-biyo fasiyes özellikleri derlenecek/ incelenecek ve bu özellikleri bakımından da birbirlerine eşdeğer olup olmadıklarının ayırımı yapılmaya çalışılacaktır.
Amaca yönelik olarak hedef bölgedeki örtü birimlerinin ayrıntılı jeolojik-paleontolojikbiyostratigrafik özellikleri ortaya konulacaktır. $\mathrm{Bu}$ yolla Orta Pontidler'de, Tokat ilinin kuzeybatısındaki Zile, Turhal ve daha güneydeki Pazar İlçesinin kuzey kesimlerini kapsayan çalışma alanının, bölgedeki jeolojik ve stratigrafik konumu yorumlanmaya çalışılacaktır.

İnceleme alanı ve yakın çevresinde 1947 yılından itibaren, değişik araştırıcılar tarafından, jeoloji amaçlı çalışmalar yapılmıştır. Baykal (1947), Blumenthal (1950), Okay (1955), Alp (1972), Seymen (1975, 1993), Öztürk, (1979), Özcan ve diğ., (1980), Görür ve diğ., (1983), Gedik ve diğ., (1983), Aktimur ve diğ., (1992), Akyazı ve Tunç (1992), Tüysüz (1993, 1996), Akay ve diğ., (1994), Yılmaz ve diğ., (1995), Üstüntaş ve İnceöz (1999) ile Atalay (2001) genel jeoloji amaçlı, Koçyiğit (1979) ve Tatar (1983) tektonik amaçlı, Yılmaz (1980, 1981), Tetiker ve diğ., (2009) petrografi amaçli, Gökçe (1983), Minaz (1984), Yalçın Erik ve Ay (2010) maden jeolojisi amaçlı çalışmalar yapmışlardır.

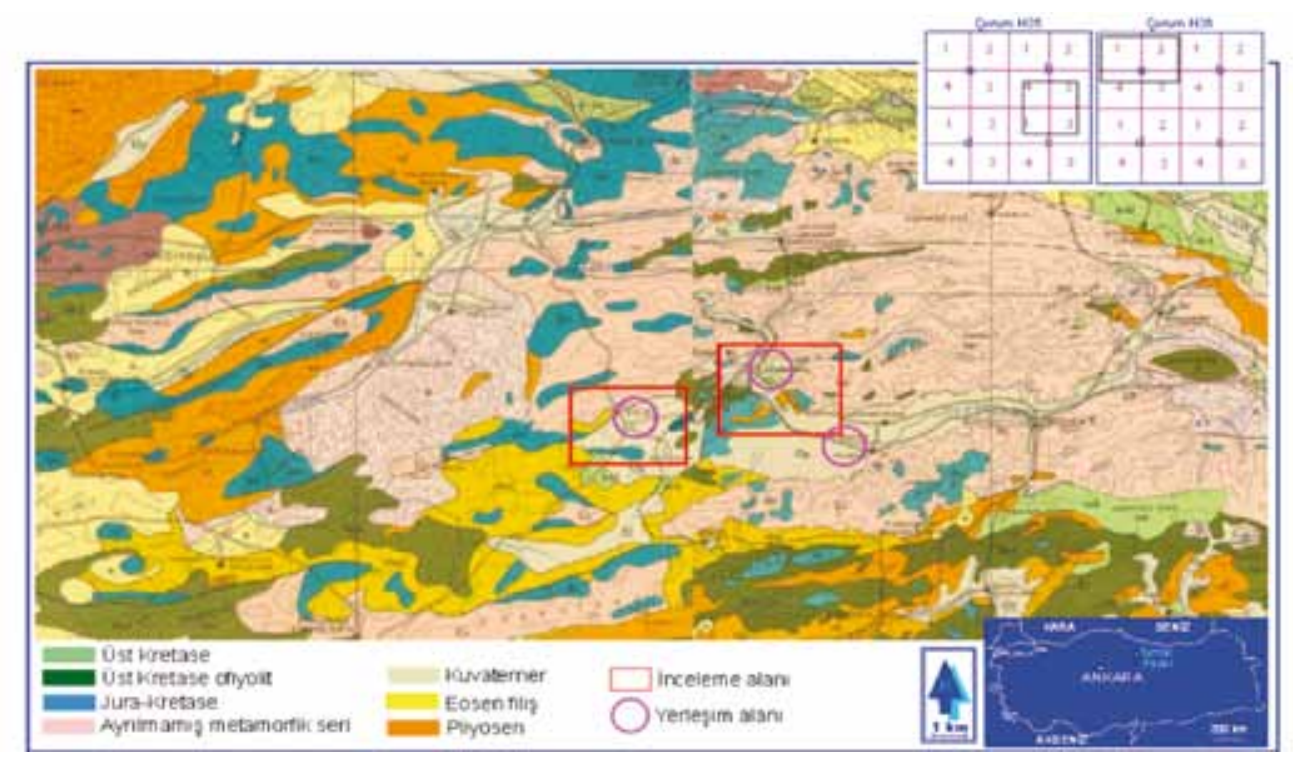

Şekil 1. İnceleme alanının yer bulduru haritası (MTA 1:250.000 ölçekli jeoloji haritası)

Figure 1. Location map of investigated area (MTA map of geology 1:250.000 scale) 


\section{GENEL JEOLOJİ}

Çalışma alanının temelini oluşturan metamorfitler; düşük derece metamorfizma ürünleri olan mikaşist, kalkşist, epidotşist, milonit-gnays, metakumtaşları ve metakuvars kumtaşlarından oluşan PermoTriyas yaşlı matriks ile bu matriks içerisinde yüzer durumda bulunan, metamorfizma öncesi havza kenarından taşınmış Permiyen yaşlı mermer bloklarından oluşmuştur (Akyazı ve Tunç, 1992).

Temel kayaları üzerine uyumsuzlukla gelen Alt-Orta Jura yaşlı birimler, metamorfik çakıllar ve Permiyen yaşı ıireçtaşı çakıllarından oluşmuş karbonat çimentolu çakıltaşlarıyla başlamaktadır. Üste doğru, koyu renkli, ince-orta taneli, orta tabakalı kumtaşları ve bunlar üzerinde sıvanım şeklinde olan, çamurtaşı, marn ve killi kireçtaşlarıyla devam etmekte olup, çökelmeyle koşut olarak gelişmiş volkanik etkinlikler sonucu çökeller içerisine aglomera, andezitik lav akıntıları, yastık lavlar ve tüfler katılmıştır.
Kırmızı-pembe renkli kireçtaşlarından oluşan Üst Jura-Alt Kretase yaşlı birimler AltOrta Jura yaşlı birimler üzerinde , killi-kumlu kireçtaşlarından oluşan Maestrihtiyen yaşlı birimler ise, Üst Jura-Alt Kretase yaşlı birimler. üzerinde açılı uyumsuzlukla yer almaktadır. Laramiyen Orojenezi ile regresyona uğrayan bölgede Lütesiyen trasgresyonu ile birlikte, Maestrihtiyen yaşlı birimler üzerine açısal uyumsuzlukla bir taban çakıltaşı ile gelen kumtaşı ve killi kireçtaşlarından oluşan bu birimlerin üzerine de açısal uyumsuzlukla, sığ deniz fasiyesi ürünleri olan; jipsli, tebeşirli ve tüflü kiltaşlarından oluşan Pliyosen yaşlı birimler gelmektedir. Çalışma alanında gözlenen en genç birimler ise, Kuvaterner yaşlı taraça çakıltaşlarıdır.

Bölgenin jeolojik evriminde Laramiyen, Anadolu ve Pireniyen fazlan oldukça önemli rol oynamışlardır. $\mathrm{Bu}$ tektonik hareketlerle KDGB doğrultulu kıvnmlanmalar ve bu kıvnm eksenlerine koşut sürüklenimler gözlenmiştir. 


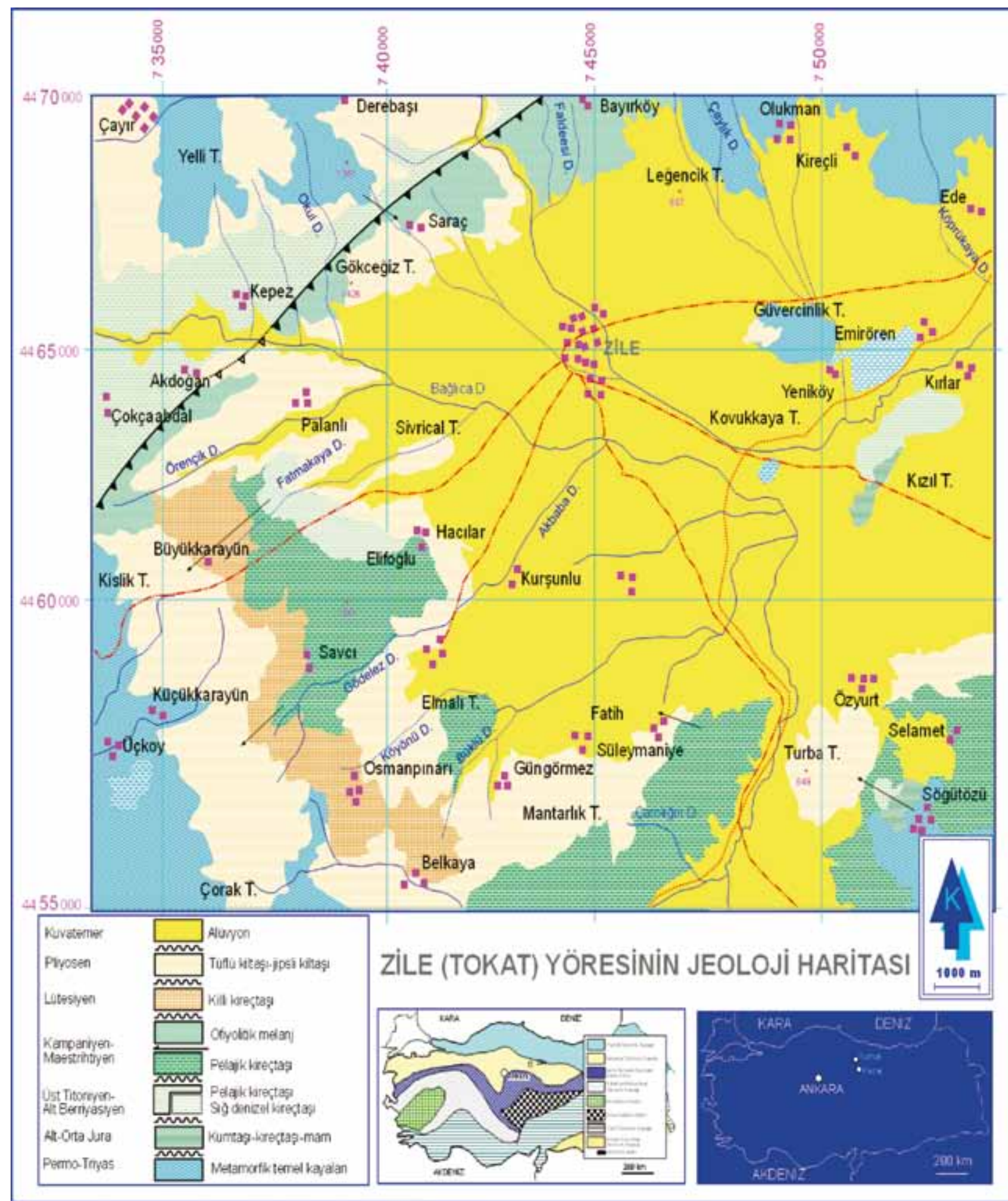

Şekil 2. Zile (Tokat) yöresinin jeoloji haritası

Figure 2. Geological map of Zile (Tokat) region 


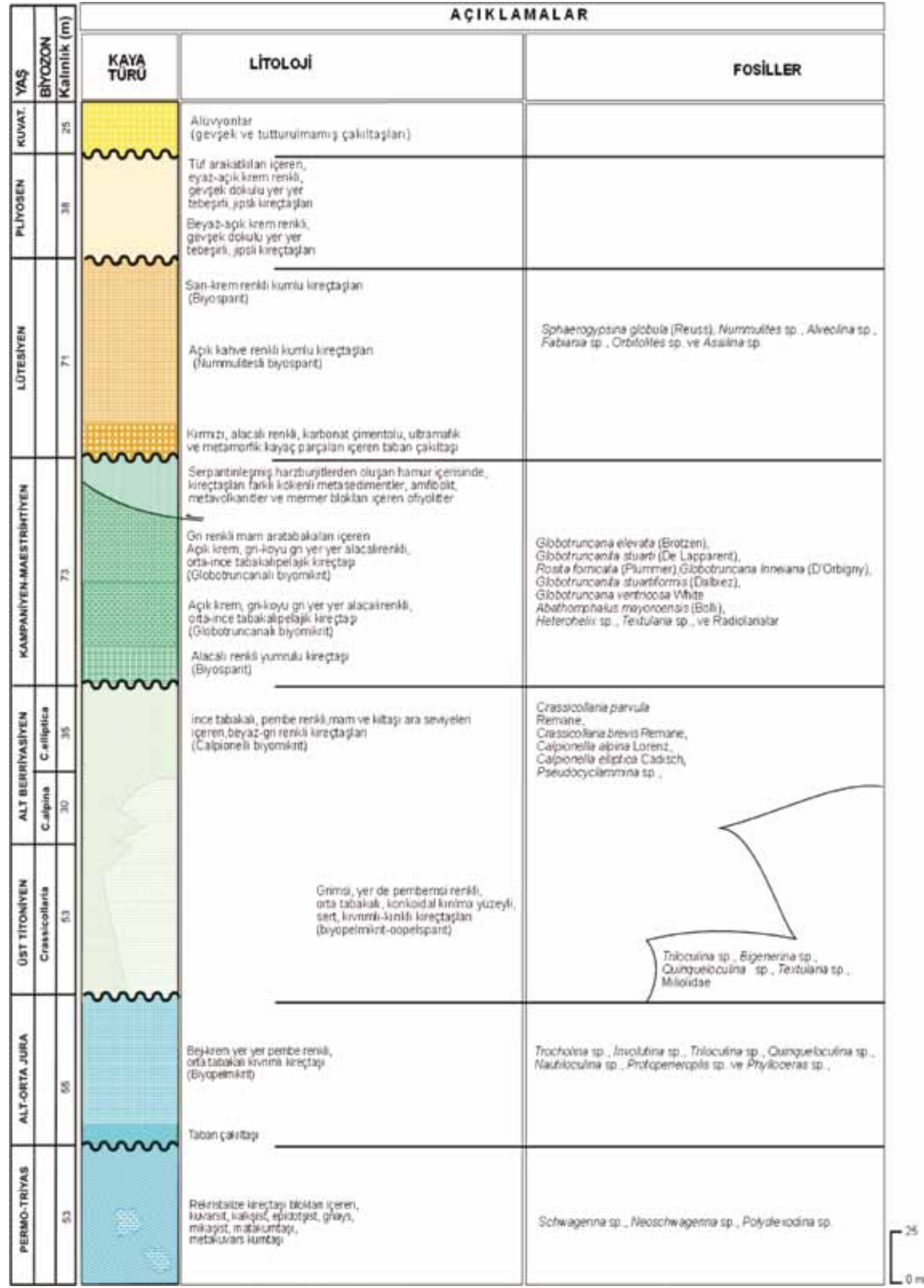

Şekil 3. Zile yöresinin stratigrafi kesiti

Figure 3. Stratigraphic section of Zile region 


\section{STRATIGRAFI}

Stratigrafik çalışma yapılan inceleme alanı, Zile ve Turhal-Pazar yöreleri olmak üzere iki bölüm halinde incelenmiştir.

\section{Zile Yöresinin Stratigrafisi}

Zile yöresinde, çökelmiş olan örtü kayaçları ile temel kayaçlar arasındaki örtü-temel ayırdımı net olarak gözlenmektedir. Permo-Triyas yaşl1 temel karmaşı̆̆ı üzerine gelen örtü birimleri Orta Jura'dan başlayarak Kuvaterner'e değin uzanan kesikli bir istif olarak izlenmektedir. Orta Jura'dan başlayarak Üst Kretase'ye kadar birbirleriyle uyumsuz olsalar da devam eden istif, Laramiyen orojenezinin etkisiyle Üst Kretase sonunda belirgin bir kesikliğe uğrar. Aynı zamanda Üst Kretase çökelimine koşut olarak gelişen ve güneyden kuzeye doğru bindiren bir ofiyolit kuşağının varlığı da gözlenmektedir. Üst Kretase çökelleri üzerine açılı uyumsuzlukla gelen sığ denizel Eosen çökeliminden sonra bölge yer yer karasallaşmış, sığ denizden karasala uzanan değişik yelpazedeki çökellerden oluşan Pliyosen yaşlı birimlerin bölgedeki varlığı gözlenmiştir (Şekil 2).

Permo-Triyas: Düşük derecede metamorfizma izleri taşıyan temel kayaları; kuvarsit, kalkşist, epidotşist, milonitgnays, mikaşist, metakumtaşı ve metakuvars kumtaşlarından oluşan metamorfik bir matriks ile bu matriks içerisinde yüzer durumda bulunan rekristalize kireçtaş1/kireçtaş1 bloklarından oluşmaktadırlar (Akyazı ve Tunç,1992). Kristalize kireçtaşlanndan alınan örneklerin ince kesitleri üzerinde yapılan çalışmalarda birim içerisinde Permiyen yaşı veren; Schwagerina sp., Neoschwagerina sp. ve Polydiexodina sp. fosilleri saptanmıştır (Akyazı ve Tunç, 1992). Bu nedenle bu çalışmada da kristalize kireçtaşlarının yaşı Permiyen olarak kabul edilmiştir.
İçerisinde Permiyen yaşlı bloklar bulunduran metamorfik matriksin üzerinde yer alan ve çalışma alanınında yüzeyleyen Üst Jura-Alt Kretase yaşlı birimlerin metamorfizma geçirmediği gözönüne alındığında, metamorfitlerinin PermoTriyas yaşında olduğu ve Üst Jura öncesi metamorfizma geçirdikleri söylenebilir (Şekil 3).

Birim inceleme alanının kuzeydoğusunda; Ede, Olukman ve Bayırköyün kuzeyi ile Güvercinlik Tepe ile Emirören-Yeniköy arasında, kuzeybatıda; Derebaşı Köyü batısıyla Yelli Tepe'de, güneydoğuda Söğütözü köyü civarında, güneybatıda ise; Kislik Tepe, Çorak Tepe ile Üçköy civarında yüzlekler vermektedir (Şekil 2).

Baykal (1947) tarafindan Paleozoyik Yaşlı Metamorfitler, Blumenthal (1950) tarafindan Tokat Kristalin Masifi, Okay (1955) tarafindan Paleozoyik Metamorfitleri, Y1lmaz ve diğ., (1995) ve Ketin (1962) tarafindan Tokat Masifi, Seymen (1975) tarafindan Tozanlı Grubu, olarak tanımlanan bu birim, Koçyiğit (1979) tarafından Tokat Grubu, Yilmaz (1980) tarafindan Tokat Formasyonu, Özcan (1980) tarafindan Turhal Grubu, Özcan ve diğ., (1980) tarafindan Turhal Metamorfitleri/Devecidağ Karışı̆̆ı, Gökçe (1983) tarafindan Turhal Metamorfitleri, Şengör ve diğ., (1985) Gölova (Agvanis) Metamorfitleri, Temiz ve diğ., (1993) tarafından Tokat Kompleksi olarak adlandırılan ve tanımlanan Erzincan'dan Amasya'ya kadar uzanan métamorfik zonun bir parçasını oluşturan bu birim Tüysüz, (1993) tarafindan ise, Karakaya Karmaşığı olarak tanımlanmıştır (Şekil 13).

Alt-Orta Jura: Alacalı renkli karbonat çimento ile sıkı bağlanmış kuvarsit, kalkşist, epidotşist, gnays, mikaşist, mermer ve Permiyen yaş1 kireçtaşı çakıllarından oluşmuş metamorfik çakıllar içeren çakııltaşlarıyla başlamakta olup, 
üste doğru, kahve yer yer siyahımsı koyu renkli, ince-orta taneli, orta tabakalı kumtaşına geçmektedir. Kumtaşları, koyu yeşil renkli, ince tabakalı çamurtaşı ile gri renkli, ince tabakalı marn ve koyu kırmızı renkli killi kireçtaşları tarafından ince bir tabaka halinde sıvanmış durumdadır. Çökelmeyle koşut olarak gelişen denizaltı volkanik etkinliklerine bağlı olarak çökeller içerisine yer yer koyu renkli, kalın tabakalı aglomera, andezitik lav akıntıları ve yastık lavlar ile açık renkli, inceorta tabakalı tüfler katılmıştır (Şekil 2, 3).

İnceleme alanındaki kalınlığ1 100-150 m olarak saptanan birime ait marnlar ve kireçtaşları içerisinde; Trocholina sp., İnvolutina sp., Triloculina sp., Quinqueloculina sp., Nautiloculina sp., Protopeneroplis sp. ve Phylloceras sp., fosilleri saptanmıştır (Akyazı ve Tunç, 1992). Saptanan bu fosillerin yanısıra birimin stratigrafik konumu gözönüne alınarak birime Alt-Orta Jura yaşı verilmiştir.

Seyrekte olsa içerisinde andezitik lav akıntıları ve yastık lavlar gözlenen birimin deniz altı volkanizmasının etkin olduğu ortamda çökeldiğini göstermektedir.

Birim, Öztürk (1979) tarafindan Seyfe, Alp (1972) tarafindan Kayabaşı, Seymen, (1975) tarafından Karatepe, Altınlı (1973) tarafindan Bayırköy, Özcan ve diğerleri (1980), tarafından Inözü, Saner, (1980) ve Gözübol (1980) tarafından Mudurnu, Serdar ve diğerleri (1984), Karakese formasyonları olarak tanımlanmış ve adlandırılmıştır (Şekil 13).

\section{Üst Titoniyen-Alt Berriyasiyen:} İnceleme alanındaki Üst Titoniyen-Alt Berriyasiyen yaşlı birimler; düşey ve yanal yönde farklı litofasiyes özelliklerine sahip olup, gel-git ortamından resif önüne hatta derin denizele kadar değişen ortamlarda çökelmiştir. Birim, inceleme alanının batısında derin denizel, doğusunda ise sığ denizelden başlayıp derin denizel fasiyese doğru geçen özellikler göstermektedir.

Doğuda Kızıltepe dolayında yüzlek veren sığ denizel birimler, grimsi, yer de pembemsi renkli, orta tabakalı, konkoidal kırılma yüzeyli, sert, kıvrımlı-kırıklı kireçtaşlarından oluşmaktadır. $\mathrm{Bu}$ kireçtaşlarının alt düzeyleri biyopelmikrit mikrobiyofasiyeste gelişmiş olup, dokusunda bol pellet ile foraminiferalarla radiolarialardan oluşan biyojen taneler içerirken, üst düzeyleri, kötü yıkanmış oolitli pelsparit mikrobiyofasiyes özellikleri gösterir ve bol olarak pellet ile alg kökenli çekirdeğe sahip oolitler içermektedir. Birime ait örneklerin ince kesitleriyle yapılan incelemeleri sonucunda, Triloculina sp, Bigenerina sp., Quinqueloculina sp., Textularia sp., ve Miliolidae gibi fosiller saptanarak birime Üst Jura-Alt Kretase yaşlı verilmiştir (Şekil 2, 3).

Birim üst düzeylerde, inceleme alanının batısında olduğu gibi, ince tabakalı, pembe renkli marn ve kiltaşı ara düzeyleri içeren, beyaz-gri renkli kireçtaşlarından oluşmaktadır. Calpionelli biyomikrit mikrobiyofasiyesinde gelişmiş olan birimin bu düzeyleri içerisinde Üst Titoniyen-Alt Berriyasiyen yaşını veren; Crassicollaria parvula Remane, (Levha I, şekil 5), Crassicollaria brevis Remane, (Levha I, şekil 4), Calpionella alpina Lorenz, Calpionella elliptica Cadisch, Pseudocyclammina sp. fosilleri saptanmıştır (Şekil 2, 3).

Birim inceleme alanının kuzeybatısında Çokçaabdal köyünden Bayırköye uzanan GBKD yönlü hattın kuzeybatısında ve güneyindeki Hacılar Köyü yöresinde, doğusunda bulunan Kızıltepe ile Kırlar Köyü arasında, güneydoğuda ise, Söğütözü Köyü civarında küçük bir alanda yüzlek vermektedir. Üst Jura-Alt Kretase yaşlı olan birim inceleme alanının güneydoğusunda tabanda neritik ortam özellikleri gösterirken, üst düzeylerinde inceleme alanının batısında olduğu 
gibi, pelajik ortam çökelim koşullarını işaret etmektedir.

Baykal, (1947) tarafindan “Ayrılmamış Mesozoyik" olarak adlandırılan birim, Blumenthal (1950), Amasya kireçtaşı, Pontid zonu Alt ve Orta Kretase kalkerleri, Altınlı (1971, 1972, 1973) Bilecik kireçtaşları, Alp (1972) CarcurumFerhatkaya Formasyonu, Seymen (1974) Hankırı Tepesikireçtaş1, Öztürk (1979) Doğdu formasyonu, Terlemez ve Yılmaz (1980) Zinav kireçtaşı olarak tanımlanan ve adlandırılan birim, Özcan ve diğ., (1980) tarafindan da birbiriyle eşlenik Ferhatkaya, Carcurum, Helvacı ve Karaömer formasyonları olarak Amasya Grubu'na dahil edilmiştir. Birim, Gökçe (1983) Buzluk Kireçtaşları, Serdar ve diğ. (1984) Inaltı Formasyonu, Yoldaş ve diğerleri (1985) Belalan kireçtaşı, Akyazı ve Tunç (1996) Sarıalan formasyonu, olarak tanımlanmış ve adlandırılmıştır (Çizelge 4)

\section{Kampaniyen-Maestrihtiyen:}

Üst

Kretase yaşlı denizel örtü birimleri, JuraKretase yaşlı birimler üzerine belirgin lakün ve hiyatüsün varlığını kanıtlayacak şekilde biyosparitik mikrobiyofasiyeste gelişmiş, alacalı renkli yumrulu kireçtaşı düzeyiyle uyumsuz olarak gelmektedir. Palecypoda ve gastropoda kavk1 parçaları ile alg içeren sparit dokulu, bu yumrulu kireçtaşları, Kampaniyen'de başlayan transgresyonunun bölgede gözlenen ve sığ deniz fasiyesinde olan ilk tortullarıdır (Şekil 3).

Hızlı gelişen transgresyon sonucu, bölge derin denizel özellik kazanmış ve buna paralel olarak, bol planktonik foraminifera içeren, açık krem, gri-koyu gri yer yer alacalı renkli, ince-orta tabakalı Globotruncanalı biyomikrit mikrobiyofasiyesindeki derin denizel kireçtaşları yumrulu kireçtaşları üzerine çökelmiştir. Birimin üst düzeylerinin bazı sınırlı alanlarda gri renkli marn tabakaları içerdiği de gözlenmiştir.
Çalışma alanında $210 \mathrm{~m}$ kalınlıkta olduğu saptanan birim, 1/25.000 ölçekli Çorum H35 b4 paftasında yeralan inceleme alanının güneydoğusunda Söğütözü ve Selamet Köyleri yöresinde, güneyde Süleymaniye yöresinde, güneybatıda Elifoğlu ve Savcı köyleri arasında kalan bölgedeki alanlarda yüzlekler verir (şekil 2).

Birime ait kireçtaşlarından elde edilen örnekler üzerinde yapılan ayrıntılı paleontoloji çalışmaları sonucunda; Globotruncana elevata (Brotzen), Globotruncanita stuarti (De Lapparent), Rosita fornicata (Plummer), Globotruncana linneiana (D’Orbigny), Globotruncanita stuartiformis Dalbiez, Globotruncana ventricosa White, Heterohelix sp, Textularia sp. ve Radiolaria fosilleri saptanarak birime KampaniyenMaestrihtiyen yaşı verilmiştir.

Birim, Alp (1972), Lokman, Özcan ve diğ., (1980), Eğerkaya, Yılmaz (1980), Boztepe Formasyonu, Koçyiğit (1979), Tekneli Grubu, Akyazı ve Tunç (1992) Hacılar, Gedik, A. ve Korkmaz, S., (1984), Akveren, Akay ve diğ.., (1994) tarafından, Yemişliçay formasyonu olarak tanımlanmış ve adlandırılmıştır (Şekil 13).

\section{Üst Kretase Ofiyolitli Karışığı: Kuzeye} ve güneye doğru bindirmeli kuşaklar şeklinde yerleşen okyanusal kabuk dilimleri ve çökel prizması bileşenlerinden oluşmakta olan ofiyolitik birimler, kuzeyden ve güneyden denizel ve karasal çökeller tarafından kuşatılmaktadır.

Üst Kretase sonrası yerleştiği düşünülen ve inceleme alanının kuzeybatısında Çokçaabdal'dan Bayırköye kadar yaklaşık güneybatı-kuzeydoğu doğrultusunda gözlenen bu birim iki ana tektonik dilimden oluşmaktadır. Tabanda yer alan dilim tipik bir ofiyolitik melanj bileşimlerinden oluşmaktadır. Serpantinleşmiş harzburjitlerden oluşan hamur içerisinde, yer yer Liyas yaşlı, kırmızı renkli, yer yer de Jura-Kretase yaşlı, gri renkli mikritik 
kireçtaşları farklı kökenli metasediment, amfibolit, metavolkanit ve mermer blokları içeren bu birim II. dilimle tektonik ilişkilidir. I. tektonik dilime göre daha düzenli bir istif sunan II. tektonik dilim serpantinleşmiş dunit, serpantinleşmiş harzburjit ve harzburjitlerden oluşmakta olup, üst düzeyleri metabazalt ve spilitik bazaltlardan oluşmaktadır.

$\mathrm{Bu}$ iki tektonik dilim birbiriyle girift olduğundan ayrı ayrı haritalanamamıştır. Ofiyolitli karışık içerisinde yer alan mafik bileşenler yeşilşist metamorfizması koşulları altında metamorfizmaya uğramışlardır (Akyazı ve Tunç, 1992).

Çalışma alanının güneyinde doğu-batı uzanımında geniş yüzlekler veren Üst Kretase yaşlı ofiyolitik dizide I. ve II. tektonik dilim arasındaki fark sadece yapısal özellikte olduğu için anlatımda yer verilmesine karşın haritalama da ayırt edilmemiştir (Şekil 2).

Lütesiyen: Lütesiyen transgresyonunun ürünü olan birimler, inceleme alanının güneybatısında, Belkaya, Büyükkarayün, Küçükkarayün köyleri arasında, yaklaşık güneydoğu-kuzeybatı doğrultulu bir alanda yüzeylemektedir. Kampaniyen-Maestrihtiyen yaşlı birimler üzerine açılı uyumsuzlukla gelen birim bir taban çakıltaşıyla başlamaktadır. Çakıltaşları, kırmızı, alacalı renkli, karbonat çimentolu, ultramafik ve metamorfik kayaç parçaları ile Üst Kretase yaşlı kireçtaşı çakılları içerir. Genellikle küçük çakıllı olmasına karşın yer yer kaba çakıl içerdiği de saptanan, intraklastik malzemeli çakııllardan oluşan bu çakıltaşları dereceli olarak, karbonat çimentolu, ortakaba taneli, gevşek dokulu kumtaşlarına geçer. Üste doğru, açık kahve renkli, Nummulitesli biyosparit mikrobiyofasiyeste gelişmiş kumlu kireçtaşlarına geçen birimin en üst kesimi sarıkrem renkli, biyosparit mikrobiyofasiyesteki kumlu kireçtaşlarından oluşmuştur.
Birime ait kireçtaşlan içerisinde, Lütesiyen yaşı veren Sphaerogypsina globula (Reuss), Nummulites sp., Alveolina sp., Fabiania sp., Orbitolites sp. ve Assilina sp. fosilleri saptanmıştır.

Özcan ve diğ., (1980) tarafından Çekerek, Gökçe (1983) tarafindan Akçatarla Çökelleri, Seymen (1993) tarafindan Cevherli, Temiz ve diğ., (1993), tarafindan Kabaklık formasyonu olarak tanımlanmış ve adlandırılmıştır (Şekil 13).

Pliyosen: İnceleme alanının kuzeybatısında, Çayır, Derebaşı ve Saraç, batısında Palanlı, güneybatısında Büyükkarayün, Küçükkarayün, doğusunda Osmanpınarı, Belkaya Köyleri civarında ve güneydoğuda Turba Tepe civarında olmak üzere geniş bir alanda yüzlekler veren ve kendisinden yaşlı tüm birimleri açılı uyumsuzlukla örten bu birimin üzerine de çalışma alanının orta kesimlerinde Kuvaterner yaşlı alüvyon gelmektedir. Birim beyaz-açık krem renkli, gevşek dokulu yer yer tebeşirli, jipsli kireçtaşlarından oluşmakta olup üst düzeylerde kiltaşı aratabakalar içermektedir. Birimin üst düzeylerinde görülen tüflü katışımlar o dönemdeki volkanik etkinliğin bir göstergesi olarak kabul edilebilir. Volkanik etkilerde zaman zaman etkili olduğu sığ, kapalı bir geçiş ortamının ürünü olan birim içerisinde fosil elde edilememesine karşın, birime, önceki çalışmalarda verilmiş olan Pliyosen yaş1, birimin stratigrafik konumu da göz önüne alınarak bu çalışmada da benimsenmiştir.

Miyosende karasallaşan bölgede beliren topografyaya bağlı olarak gelişmiş vadi dolguları ve yama şeklinde örtüler olarak izlenir. Jipsli aratabakalar içeren birim, sergilediği tortul yapılara göre, sıcak ve kurak iklim koşullarında, dağ eteği, alüvyal yelpaze, geçişli örgülü nehir ve taşkın ovası ortamlarında çökelmiştir (Şekil 2, 3). 
Birim, Özcan ve diğ. (1980) tarafından Kemerkaş, Alp (1972) tarafından Karasal Neojen çökelleri, Öztürk (1979) tarafindan Çerkeş, Koçyiğit (1979) tarafından Boyunpınar, Yilmaz (1981) tarafindan Kargin, Seymen (1975) tarafindan Gökköy formasyonu ve Barka (1984) tarafindan Alt Pontus formasyonu olarak tanımlanmış ve adlandırılmıştır (Şekil 13).

Kuvaterner: Çalışma alanının en genç birimleri, Bağlıca, Akbaba, Köprülkaya ve Falderelerinin beslediği Zile ovasını oluşturan ve çalışma alanının orta kesimindeki geniş düzlükleri kapsayan Kuvaterner yaşlı alüvyonlardır.

\section{Zile Yöresi Ölçülü Stratigrafi Kesitleri}

Saraç Ölçülü Stratigrafi Kesiti: İnceleme alanın kuzeybatısında yeralan Saraç Köyünün kuzeybatısından başlanarak KB-GD dpğrultusunda alınan bu kesit, 4465850 enlem, 739930 boylam başlangıç ve 4465790 enlem 740040 boylam bitiş koordinatları arasında, KB-GD yönünde 685 m gidişli olup, toplam $140 \mathrm{~m}$ kalınlık ölçülmüş ve 30 örnek derlenmiştir (Şekil 4).

Kesit alınan yerde tabanda, düşük derecede metamorfizma izleri taşıyan temel kayaları yer almaktadır. Permo-Triyas yaşlı bu birim; kuvarsit, kalkşist, epidotşist, milonitgnays, mikaşist, metakumtaşı ve metakuvars kumtaşlarından oluşan metamorfik bir matriks ile bu matriks içerisinde yüzer durumda bulunan rekristalize kireçtaş1/kireçtaş1 bloklarından oluşmakta olup kireçtaşı blokları içerisinde Polydiexodina sp. (Levha III, şekil 2) fosili saptanmıştır.

Permo-Triyas yaşlı birimler üzerine uyumsuzlukla gelen, Titonik fasiyeste gelişmiş, Alt Berriyasiyen yaşlı birimler; pembe renkli marn ve kiltaşı ara düzeyleri içeren, beyaz-gri renkli kireçtaşlarından oluşmaktadır. Calpionelli biyomikrit mikrobiyofasiyesinde gelişmiş olan birimin içerisinde, Calpionella alpina Lorenz (Levha I, şekil 6) ve Calpionella elliptica Cadisch, Pseudocyclammina sp. ve Radiolaria sp. (Levha III, şekil 5) fosilleri saptanmış ve Calpionella alpina-Calpionella elliptica biyozonları tanımlanmıştır (Şekil 4).

Kesit bölgesinde, Üst Tithoniyen-Alt Berriyasiyen yaşlı kireçtaşları üzerine, tektonik olarak, Üst Kretase ve/veya sonrası yerleştiği düşünülen Ofiyolitli karışık gelmektedir.

Kesit bölgesinde, Üst TithoniyenAlt Berriyasiyen yaşlı kireçtaşları üzerine, Kampaniyen'de başlayan transgresyonunun bölgede gözlenen ve sığ deniz fasiyesinde olan ilk tortulları olan biyosparitik mikrobiyofasiyeste gelişmiş, alacalı renkli yumrulu kireçtaşı düzeyiyle başlayan Kampaniyen-Maestrihtiyen yaşlı birimler uyumsuz olarak gelmektedir.

Hizlı gelişen transgresyon sonucunda oluşan derin denizel ortam ürünleri olan, bol planktonik foramİnifera içeren, açı krem, gri-koyu gri yer yer alacalı renkli, inceorta tabakalı Globotruncanalı biyomikrit mikrobiyofasiyesindeki derin denizel kireçtaşları yumrulu kireçtaşları üzerine çökelmiştir. Birimin üst düzeylerinin bazı sınırlı alanlarda gri renkli marn tabakaları içerdiği de gözlenmiştir.

Birime ait kireçtaşlarından elde edilen örnekler üzerinde yapılan ayrıntılı paleontoloji çalışmaları sonucunda; Globotruncana elevata (Brotzen) (Levha I, şekil 15), Globotruncanita stuarti(DeLapparent), Rositafornicata(Plummer), Globotruncana linneiana (D’Orbigny), Globotruncanita stuartiformis Dalbiez (Levha I, şekil 19), Globotruncana ventricosa White ve Heterohelix $\mathrm{sp}$, fosilleri saptanmıştır.

Kesit alınan yerde, Lütesiyen transgresyonunun ürünü olan birimler, Kampaniyen-Maestrihtiyen yaşlı birimler 


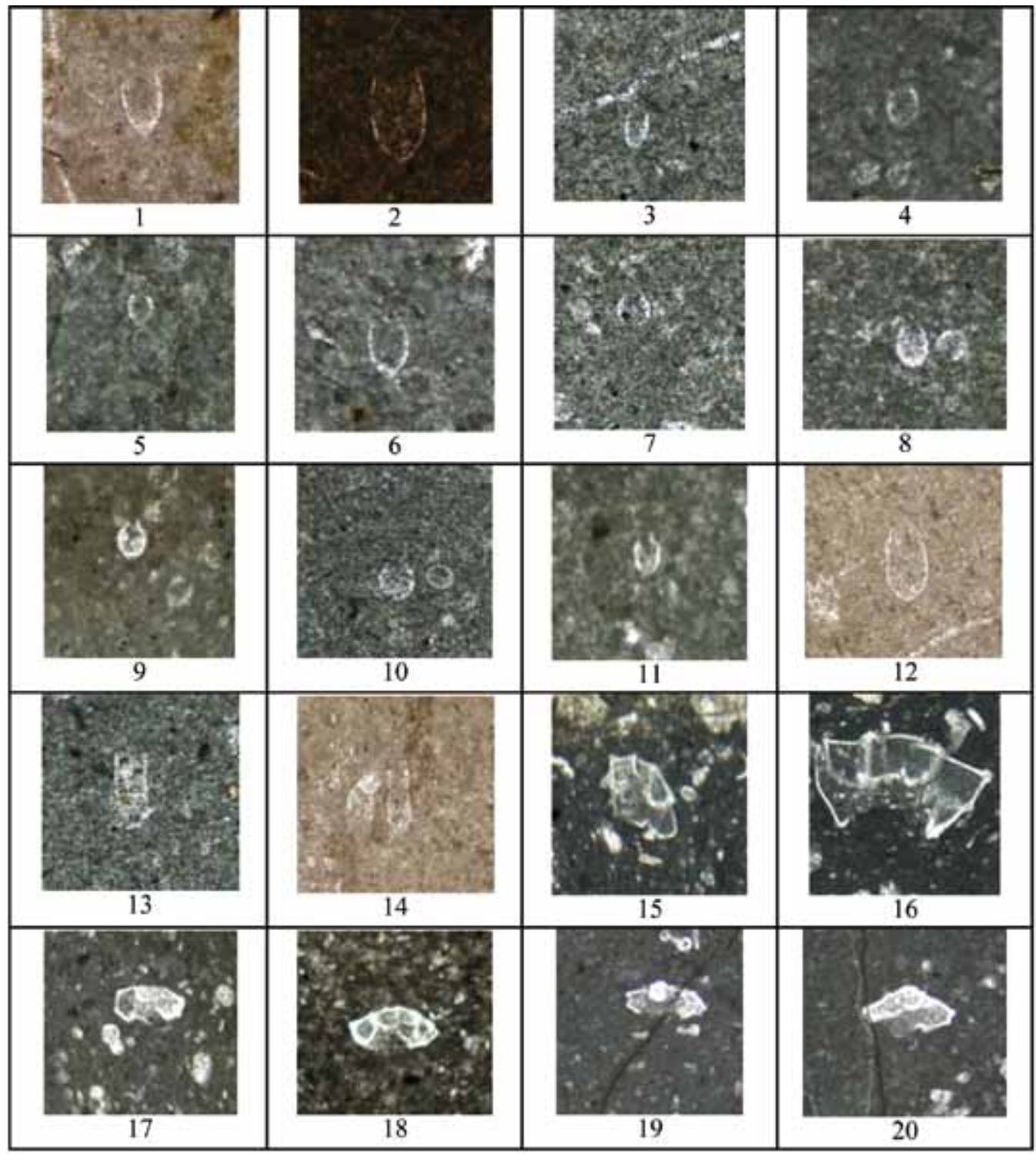

Levha I

Tintinnopsella carpathica (Murgeanui \& Filipescu)

Şekil 1. Eksenel kesit X100, Sırakayalar ölçülü stratigrafi kesiti, örnek no: Srk 25

Tintinnopsella longa (Colom)

Şekil 2. Eksenel kesit X100, Çengelkaya ölçülü stratigrafi kesiti, örnek no: Çk 30

Crassicollaria intermedia Cadisch

Şekil 3. Eksenel kesit X100, Çengelkaya ölçülü stratigrafi kesiti, örnek no: Çk 7

Crassicollaria brevis Remane,

Şekil 4. Eksenel kesit X100, Büyükkarayün ölçülü stratigrafi kesiti, örnek no: BK 9
Crassicollaria parvula Remane

Şekil 5. Eksenel kesit X100, Büyükkarayün ölçülü stratigrafi kesiti, örnek no: BK 12

Calpionella alpina Lorenz

Şekil 6. Eksenel kesit X100, Saraç ölçülü stratigrafi kesiti, örnek no: Srç 12

Şekil 7. Eksenel kesit X100, Söğütözü ölçülü stratigrafi kesiti, örnek no: Sğt 27

Şekil 8. Eksenel kesit X100, Söğütözü ölçülü stratigrafi kesiti, örnek no: Sğt 21

Şekil 9. Eksenel kesit X100, Büyükkarayün ölçülü stratigrafi kesiti, örnek no: BK 15

Şekil 10. Eksenel kesit X100, Büyükkarayün ölçülü stratigrafi kesiti, örnek no: BK 18 
Calpionella elliptica Cadisch

Şekil 11. Eksenel kesit X100, Söğütözü ölçülü stratigrafi kesiti, örnek no: Sğt 34

Şekil 12. Eksenel kesit X100, Sırakayalar ölçülü stratigrafi kesiti, örnek no: Srk 27

Calpionellopsis simplex (Colom)

Şekil 13. Eksenel kesit X100, Sırakayalar ölçülü stratigrafi kesiti, örnek no: Srk 33

Calpionellopsis oblonga Cadisch

Şekil 14. Eksenel kesit X100, Çengelkaya ölçülü stratigrafi kesiti, örnek no: Çk 35

Globotruncanita elevata (Brotzen)

Şekil 15. Eksenel kesit X100, Büyükkarayün ölçülü stratigrafi kesiti, örnek no: BK 31

üzerine bir taban çakıltaşıyla açılı uyumsuzlukla gelmektedir. Çakıltaşları, kırmızı, alacalı renkli, karbonat çimentolu, ultramafik ve metamorfik kayaç parçaları ile Üst Kretase yaşı kireçtaşı çakılları içerir. Üste doğru, açık kahve renkli, Nummulitesli biyosparit mikrobiyofasiyeste gelişmiş kumlu kireçtaşlarına geçen birimin

\section{Globotruncanita stuarti De Lapparent}

Şekil 16. Eksenel kesit X20, Süleymaniye ölçülü stratigrafi kesiti, örnek no:S1 33

Globotruncana linneiana De Lapparent

Şekil 17. Eksenel kesit X20, Savcı ölçülü stratigrafi kesiti, örnek no: Svc15

Rosita fornicata Plummer

Şekil 18. Eksenel kesit X20, Savcı ölçülü stratigrafi kesiti, örnek no: Sve 30

Globotruncanita stuartiformis De Lapparent

Şekil 19. Eksenel kesit X20, Büyükkarayün ölçülü stratigrafi kesiti, örnek no: BK 40 Globotruncana ventricosa White

Şekil 20. Eksenel kesit X20, Söğütözü ölçülü stratigrafi kesiti, örnek no: Sğt 46

en üst kesimi sarı-krem renkli, biyomikrit mikrobiyofasiyesteki pelajik killi kireçtaşlarından oluşmuştur. Birime ait kireçtaşlan içerisinde, Sphaerogypsina globula (Reuss) (Levha II, şekil 6), Nummulites sp. Orbitolites sp. (Levha III, şekil 1) ve Alveolina sp. (Levha II, şekil 5) fosilleri saptanmıştır. 


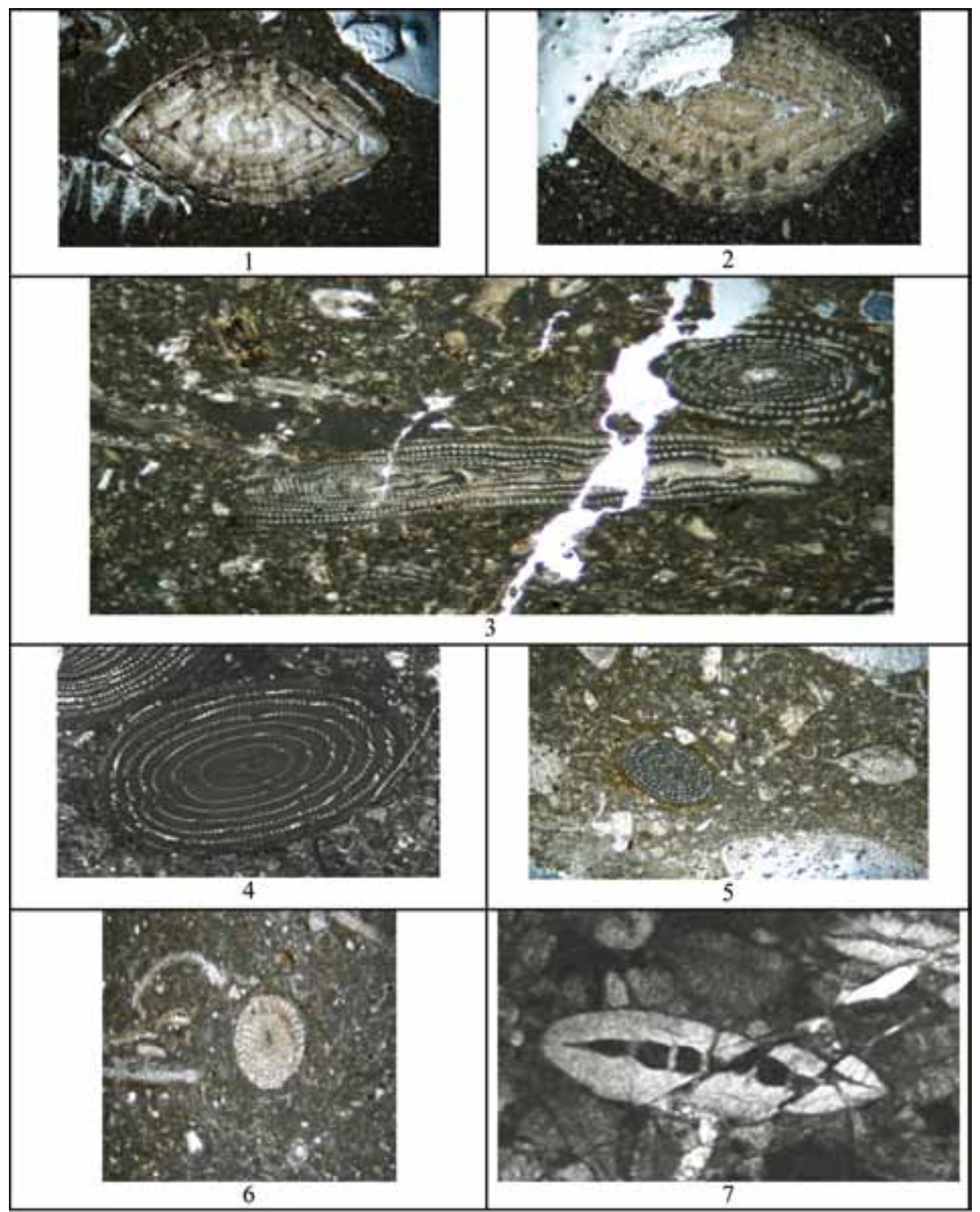

\section{Levha II}

\section{Nummulites sp.}

Şekil 1. Eksenel kesit X8, Savcı ölçülü stratigrafi kesiti, örnek no: Svc 43

Şekil 2. Eksenel kesit X8, Süleymaniye ölçülü stratigrafi kesiti, örnek no: S1 42 Alveolina sp.

Şekil 3. Eksenel kesit X8, Savcı ölçülü stratigrafi kesiti, örnek no: Svc 53

Şekil 4. Eksenel kesit X8, Süleymaniye ölçülü stratigrafi kesiti, örnek no: Sl 47
Alveolina sp.

Şekil 5. Ekvatoryal kesit X8, Büyükkarayün ölçülü stratigrafi kesiti, örnek no: BK 56

Sphaerogypsina globula (Reuss)

Şekil 6. Ekvatoryal kesit X10, Büyükkarayün ölçülü stratigrafi kesiti, örnek no: BK 48 Assilina sp.

Şekil 7. Eksenel kesit X8, Savcı ölçülü stratigrafi kesiti, örnek no: Svc 47 


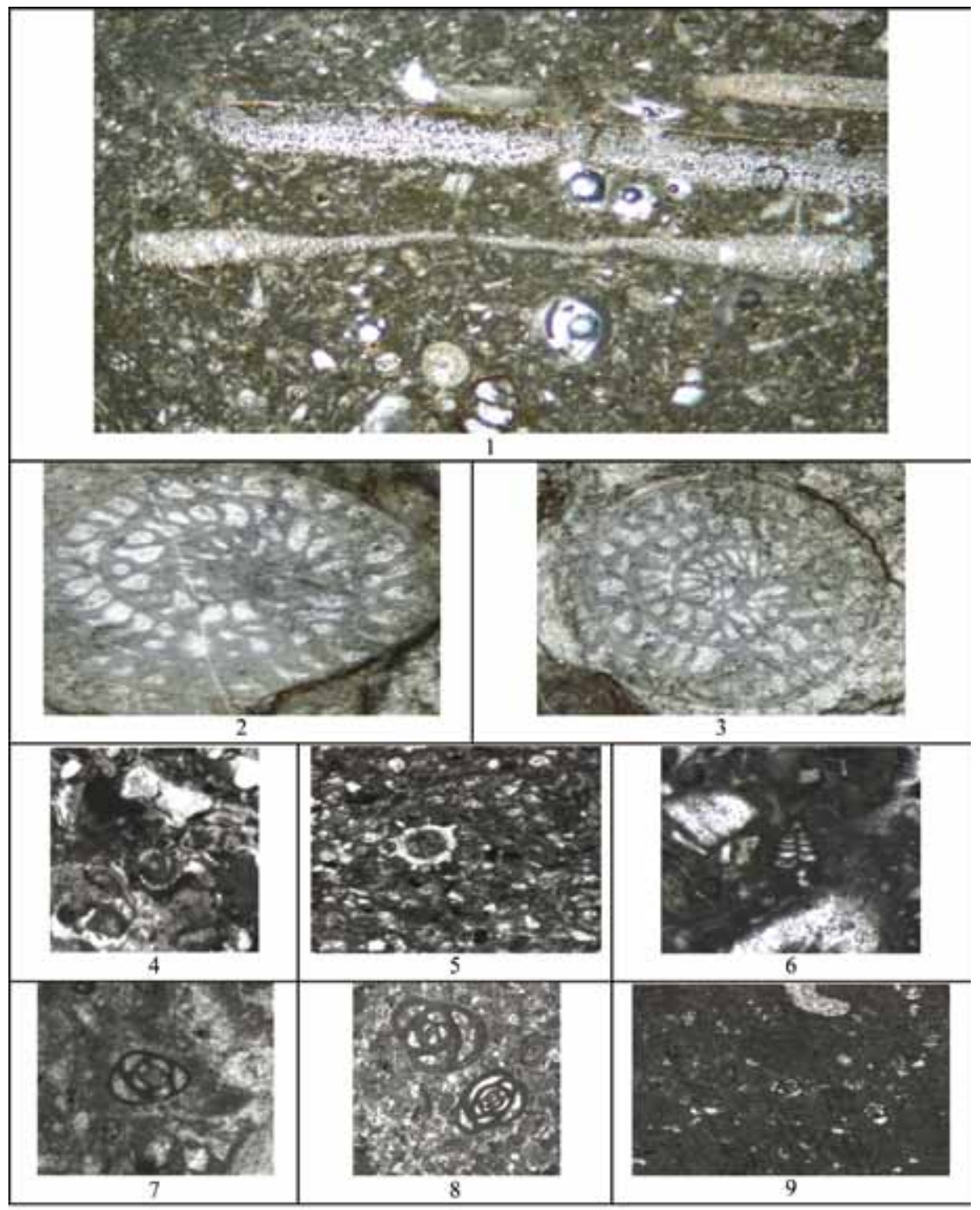

\section{Levha III}

Orbitolites sp.

Şekil 1. $\quad$ Eksenel kesit, X 20, Büyükkarayün ölçülü stratigrafi kesiti, örnek no: BK 56

Polydiexodina sp.

Şekil 2. Ekvatoryal kesit, X8, Saraç ölçülü stratigrafi kesiti, örnek no:Srç 5

Schwagerina sp.

Şekil 3. Ekvatoryal kesit, X8, Sırakaya ölçülü stratigrafi kesiti, örnek no:Srk 7

Protopeneroplis striata Weynschenk

Şekil 4. Ekvatoryal kesit, X10, Mercimek Dağ1 ölçülü stratigrafi kesiti, örnek no: Mr 15

\section{Radiolaria sp.}

Şekil 5. X20, Saraç ölçülü stratigrafi kesiti, örnek no:Srç 14

Textularia sp.

Şekil 6. Boyuna kesit, X20, Söğütözü ölçülü stratigrafi kesiti, örnek no:Sğt 3

Triloculina sp.

Şekil 7. Boyuna kesit, X20, Söğütözü ölçülü stratigrafi kesiti, örnek no: Sğt 43

Quinquleoculina sp.

Şekil 8. Boyuna kesit X20, Söğütözü ölçülü stratigrafi kesiti, örnek no: Sğt 13

Miliolidae

Şekil 9. Boyuna kesit, X20, Söğütözü ölçülü stratigrafi kesiti, örnek no: Sğt 11 
Lütesiyen yaşlı birimler üzerine açısal uyumsuzlukla gelen Pliyosen yaşlı birimler, beyaz-açık krem renkli, gevşek dokulu yer yer tebeşirli, jipsli kireçtaşlarından oluşmakta olup üst düzeylerde kiltaşı aratabakalar içermektedir. Birimin üst düzeylerinde görülen tüflü katışımlar o dönemdeki volkanik etkinliğin bir göstergesi olarak kabul edilebilir. Volkanik etkilerde zaman zaman etkili olduğu sığ, kapalı bir geçiş ortamının ürünü olan birim içerisinde fosil elde edilememesine karşın, birime, önceki çalışmalarda verilmiş olan Pliyosen yaşı, birimin stratigrafik konumu da göz önüne alınarak bu çalışmada da benimsenmiştir (Şekil 5).

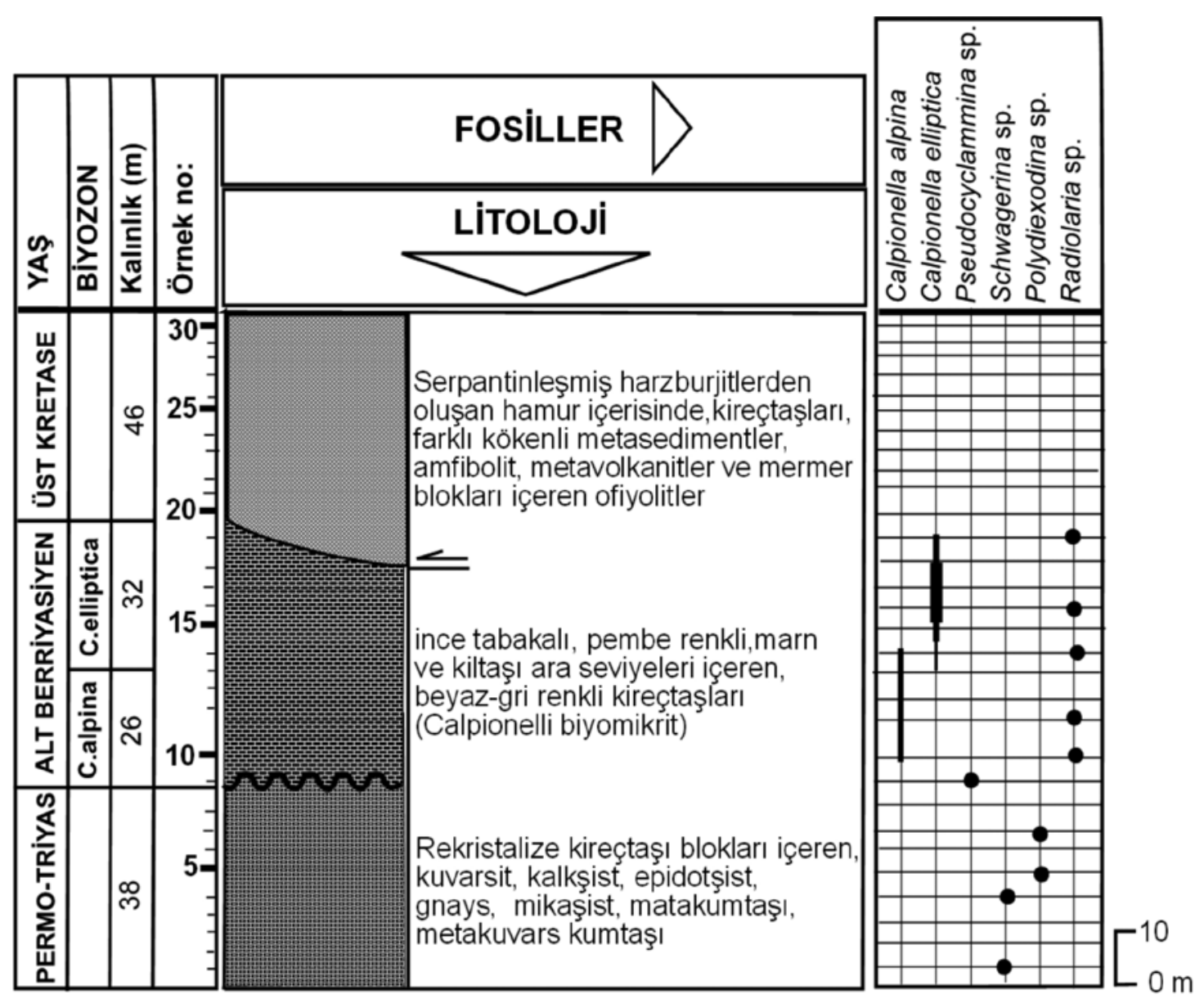

Şekil 4. S Saraç Ölçülü stratigrafi kesiti

Figure 4. Saraç measured stratigraphic section 

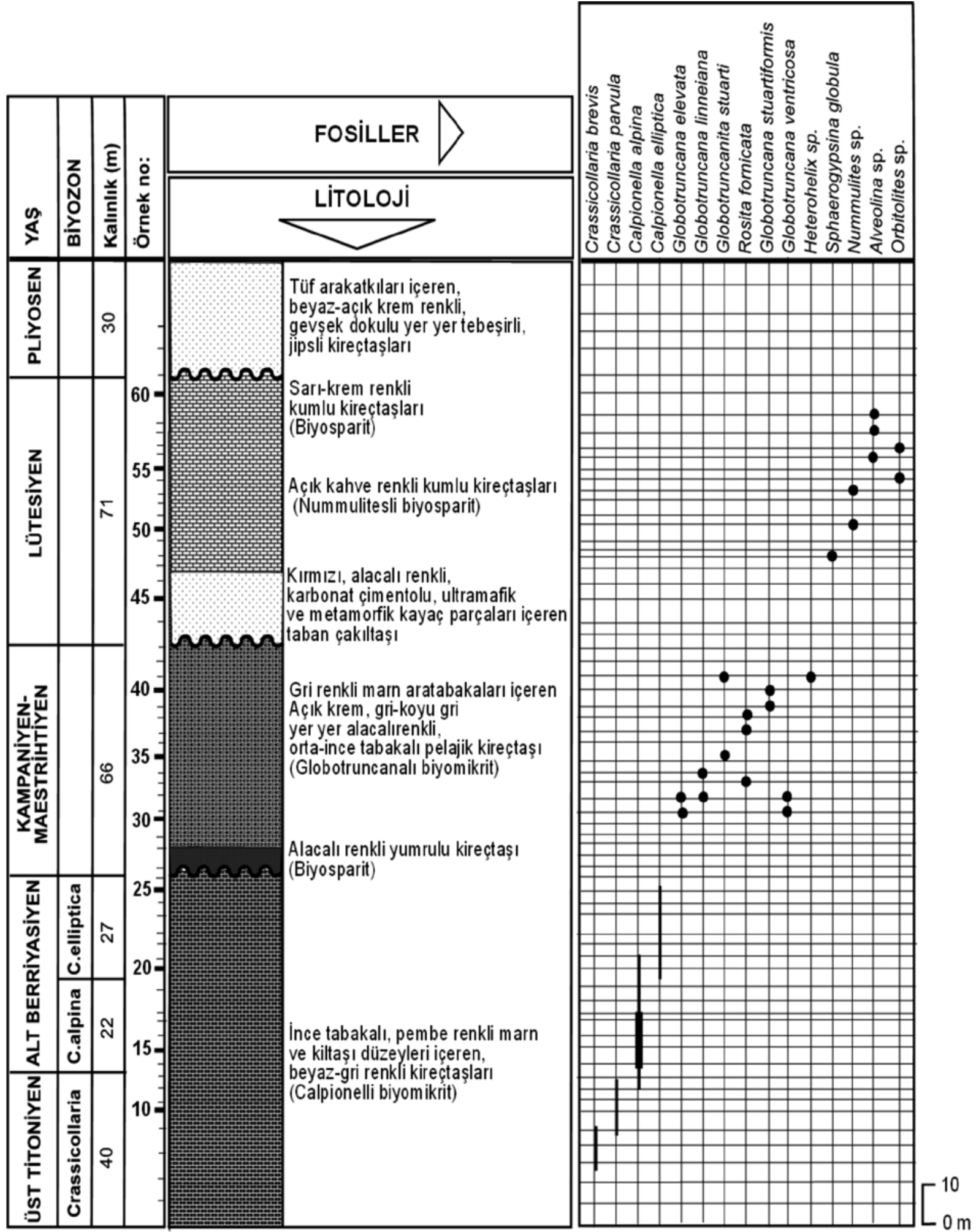

Şekil 5. Büyükkarayün ölçülü stratigrafi kesiti

Figure 5. Büyükkarayün measured stratigraphic section 
Savcı Ölçülü Stratigrafi Kesiti: İnceleme alanın güneybatısındaki Savcı Köyünün güneyindeki Gödellez Deresinden başlanarak alınan bu kesit, 4457900 enlem, 737210 boylam başlangıç ve 4457170 enlem 736685 boylam bitiş koordinatları arasında, yaklaşık KD-GB yönünde $1068 \mathrm{~m}$ gidişlidir. $\mathrm{Bu}$ kesitte toplam 133 m kalınlık ölçülmüş ve 59 örnek derlenmiştir (Şekil 2).

Kesit alınan yerde tabanda, KampaniyenMaestrihtiyen yaşlı üst düzeylerinde gri renkli marn tabakaları da içeren açık krem, gri-koyu gri yer yer alacalı renkli, ince-orta tabakalı Globotruncanalı biyomikrit mikrobiyofasiyesindeki derin denizel kireçtaşları gözlenmiştir. Bunlar Kampaniyen'de başlayan transgresyonunun ilerleyen evrelerinde hızla derinleşen bölgede gözlenen derin deniz fasiyesinde ki çökellerdir.

Birime ait kireçtaşlarından elde edilen örnekler üzerinde yapılan ayrıntılı paleontoloji çalışmaları sonucunda; Globotruncana elevata (Brotzen), Globotruncanita stuarti (De Lapparent), Rosita fornicata (Plummer) (Levha I, şekil 18), Globotruncana linneiana (D’Orbigny) (Levha I, şekil 17), Globotruncanita stuartiformis Dalbiez, Globotruncana ventricosa White, ve Heterohelix sp. fosilleri saptanmıştır.
Kesit alınan yerde, Lütesiyen transgresyonunun ürünü olan birimler, Kampaniyen-Maestrihtiyen yaşlı birimler üzerine bir taban çakıltaşıyla açılı uyumsuzlukla gelmektedir. Çakıltaşları, kırmızı, alacalı renkli, karbonat çimentolu, ultramafik ve metamorfik kayaç parçaları ile Üst Kretase yaşlı kireçtaşı çakılları içerir. Üste doğru, açık kahve renkli, Nummulitesli biyosparit mikrobiyofasiyeste gelişmiş kumlu kireçtaşların içerisinde, Nummulites sp. (Levha II, şekil 1), Alveolina sp. (Levha II, şekil 3), Assilina sp. (Levha II, şekil 7) fosilleri saptanmıştır (Şekil 6).

Lütesiyen yaşlı birimler üzerine açısal uyumsuzlukla gelen Pliyosen yaşlı birimler, beyaz-açık krem renkli, gevşek dokulu yer yer tebeşirli, jipsli kireçtaşlarından oluşmakta olup üst düzeylerde kiltaşı aratabakalar içermektedir. Birimin üst düzeylerinde görülen tüflü katışımlar o dönemdeki volkanik etkinliğin bir göstergesi olarak kabul edilebilir.

Volkanik etkilerde zaman zaman etkili olduğu sığ, kapalı bir geçiş ortamının ürünü olan birim içerisinde fosil elde edilememesine karşın, birime, önceki çalışmalarda verilmiş olan Pliyosen yaşı, birimin stratigrafik konumu da göz önüne alınarak bu çalışmada da benimsenmiştir. 

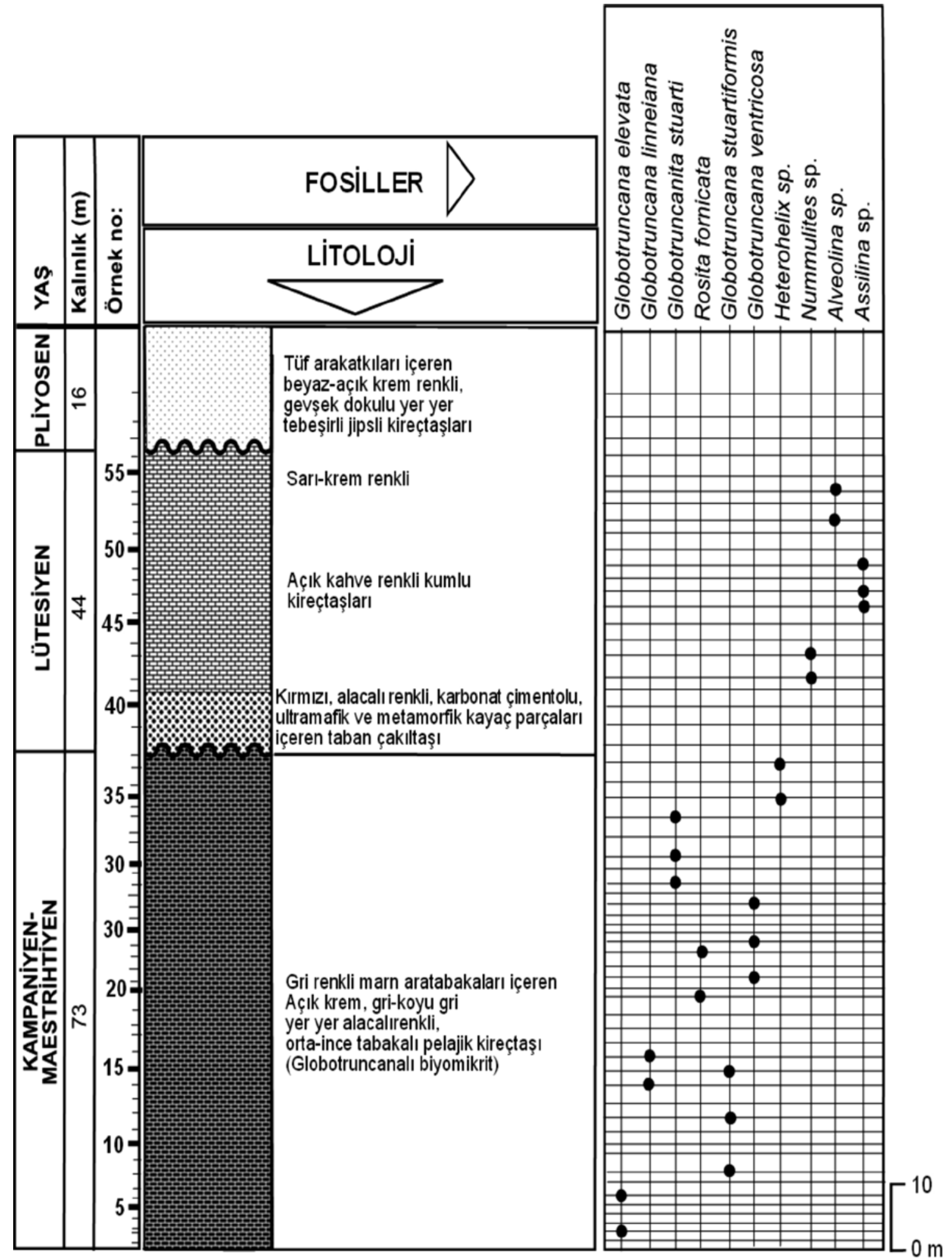

Şekil 6. Savcı ölçülü stratigrafi kesiti

Figure 6. Savcı measured stratigraphic section 
Söğütözü Ölçülü Stratigrafi Kesiti: İnceleme alanın güneydoğusundaki Söğütözü Köyünden başlanarak, kuzeybatıdaki Torba Tepeye doğru alınan bu kesit, 4456350 enlem, 7 52400 boylam başlangıç ve 4456910 enlem 751 050 boylam bitiş koordinatları arasında, yaklaşık GD-KB yönünde $1102 \mathrm{~m}$ gidişlidir. $\mathrm{Bu}$ kesitte toplam 387 m kalınlık ölçülmüş ve 66 örnek derlenmiştir (Şekil 2).

Kesit alınan yerde tabanda, düşük derecede metamorfizma izleri taşıyan temel kayaları yer almaktadır. Permo-Triyas yaşlı bu birim; kuvarsit, kalkşist, epidotşist, milonitgnays, mikaşist, metakumtaşı ve metakuvars kumtaşlarından oluşan metamorfik bir matriks ile bu matriks içerisinde yüzer durumda bulunan rekristalize kireçtaş1/kireçtaşı bloklarından oluşmakta olup kireçtaşı blokları içerisinde Polydiexodina sp. fosili saptanmıştır.

Permo-Triyas yaşlı birimin üzerinde uyumsuzlukla yer alan, Alt-Orta Jura yaşı birimler, alacalı renkli karbonat çimento ile sık1 bağlanmış kuvarsit, kalkşist, epidotşist, gnays, mikaşist, mermer ve Permiyen yaşlı kireçtaşı çakıllarından oluşmuş metamorfik çakıllar içeren çakıltaşlarıyla başlamakta olup, üste doğru, kahve, yer yer siyahımsı koyu renkli, ince-orta taneli, orta tabakalı kumtaşına geçmektedir. Kumtaşları, koyu yeşil renkli, ince tabakalı çamurtaşı ile gri renkli, ince tabakalı marn ve koyu kırmızı renkli killi kireçtaşları tarafından ince bir tabaka halinde sıvanmış durumdadır.

Kesit alınan yerde 100-150 m kalınlıkta olduğu saptanan birime ait marnlar ve kireçtaşları içerisinde; Trocholina sp. Involutina sp., Triloculina sp.(Levha III, şekil7), Quinqueloculina sp., Nautiloculina sp., Protopeneroplis sp. ve Phylloceras sp., fosilleri saptanmıştır.

Alt-Orta Jura yaşlı birimler üzerine uyumsuzlukla gelen, Titonik fasiyeste gelişmiş,
Üst Titoniyen-Alt Berriyasiyen yaşlı birimler; düşey ve yanal yönde farklı litofasiyes özelliklerine sahip olup, gel-git ortamından resif önüne hatta derin denizele kadar değişen ortamlarda çökelmiştir. Birim, inceleme alanının batısında derin denizel, doğusunda ise sı̆̆ denizelden başlayıp derin denizel fasiyese doğru geçen özellikler göstermektedir.

Birimin tabanını oluşturan sı $\breve{g}$ denizel oluşuklar, alt düzeylerde biyopelmikrit mikrobiyofasiyeste gelişmiş olup, dokusunda bol pellet ile foraminiferalarla radiolarialardan oluşan biyojen taneler içerirken, üst düzeyleri, kötü yıkanmış oolitli pelsparit mikrobiyofasiyes özellikleri gösterir ve bol olarak pellet ile alg kökenli çekirdeğe sahip oolitler içermektedir. Birime ait örneklerin ince kesitleriyle yapılan incelemeleri sonucunda, Triloculina sp, Bigenerina sp., Quinqueloculina sp. (Levha III, şekil 8), Textularia sp. (Levha III, şekil 6), ve Miliolidae (Levha III, şekil 9) gibi fosiller saptanarak birime Üst Jura-Alt Kretase yaşlı verilmiştir.

Üste doğru birim, İnce tabakalı, pembe renkli marn ve kiltaşı ara düzeyleri içeren, beyaz-gri renkli kireçtaşlarından oluşmaktadır. Calpionelli biyomikrit mikrobiyofasiyesinde gelişmiş olan birimin Üst Titoniyen düzeyleri içerisinde, Crassicollaria parvula Remane, Crassicollaria brevis Remane ve Calpionella alpina Lorenz fosilleri saptanmış ve Crassicollaria biyozonu tanımlanmıştır. Birimin Alt Berriyasiyen yaşlı düzeylerinde, Calpionella alpina Lorenz (Levha I, şekil 7-8) ve Calpionella elliptica Cadisch (Levha I, şekil 11), Pseudocyclammina sp., fosilleri saptanmış ve Calpionella alpinaCalpionella elliptica biyozonları tanımlanmıştır.

Kesit bölgesinde, Üst TithoniyenAlt Berriyasiyen yaşlı kireçtaşları üzerine, Kampaniyen-Maestrihtiyen yaşlı birimler 
biyosparitik mikrobiyofasiyeste gelişmiş, alacalı renkli yumrulu kireçtaşı düzeyiyle uyumsuz olarak gelmektedir. Palecypoda ve gastropoda kavkı parçaları ile alg içeren sparit dokulu, bu yumrulu kireçtaşları, Kampaniyen'de başlayan transgresyonunun bölgede gözlenen ve sığ deniz fasiyesinde olan ilk tortullarıdır.

Bol planktonik foramİnifera içeren, açık krem, gri-koyu gri yer yer alacalı renkli, ince-orta tabakalı Globotruncanalı biyomikrit mikrobiyofasiyesindeki derin denizel kireçtaşları yumrulu kireçtaşları üzerine çökelmiştir.

Birime ait kireçtaşlarından elde edilen örnekler üzerinde yapılan ayrıntılı paleontoloji çalışmaları sonucunda; Globotruncana elevata (Brotzen), Globotruncanita stuarti (De Lapparent), Rosita fornicata (Plummer), Globotruncana linneiana (D’Orbigny), Globotruncanita stuartiformis Dalbiez, Globotruncana ventricosa White (Levha I, şekil 20), Heterohelix sp, Textularia sp. ve Radiolaria fosilleri saptanmıştır.
Kesit alınan yerde, Lütesiyen transgresyonunun ürünü olan birimler, Kampaniyen-Maestrihtiyen yaşlı birimler üzerine bir taban çakıltaşıyla açılı uyumsuzlukla gelmektedir. Çakıltaşları, kırmızı, alacalı renkli, karbonat çimentolu, ultramafik ve metamorfik kayaç parçaları ile Üst Kretase yaşlı kireçtaşı çakılları içerir. Üste doğru, açık kahve renkli, Nummulitesli biyosparit mikrobiyofasiyeste gelişmiş kumlu kireçtaşların içerisinde, Nummulites sp., Alveolina sp., Assilina sp. fosilleri saptanmıştır (Şekil 7).

Lütesiyen yaşlı birimler üzerine açısal uyumsuzlukla gelen Pliyosen yaşlı birimler, beyaz-açık krem renkli, gevşek dokulu yer yer tebeşirli, jipsli kireçtaşlarından oluşmakta olup üst düzeylerde kiltaşı aratabakalar içermektedir. Sığ, kapalı bir geçiş ortamının ürünü olan birim içerisinde fosil elde edilememesine karşın, birime, önceki çalışmalarda verilmiş olan Pliyosen yaş1, birimin stratigrafik konumu da göz önüne alınarak bu çalışmada da benimsenmiştir. 

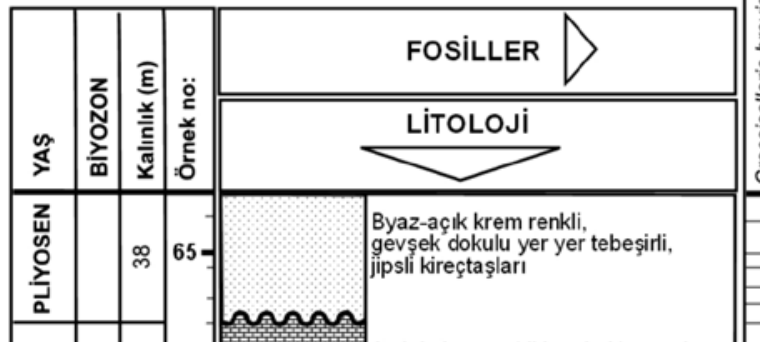

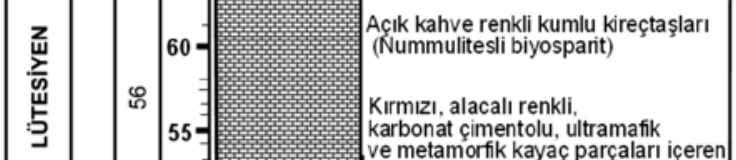
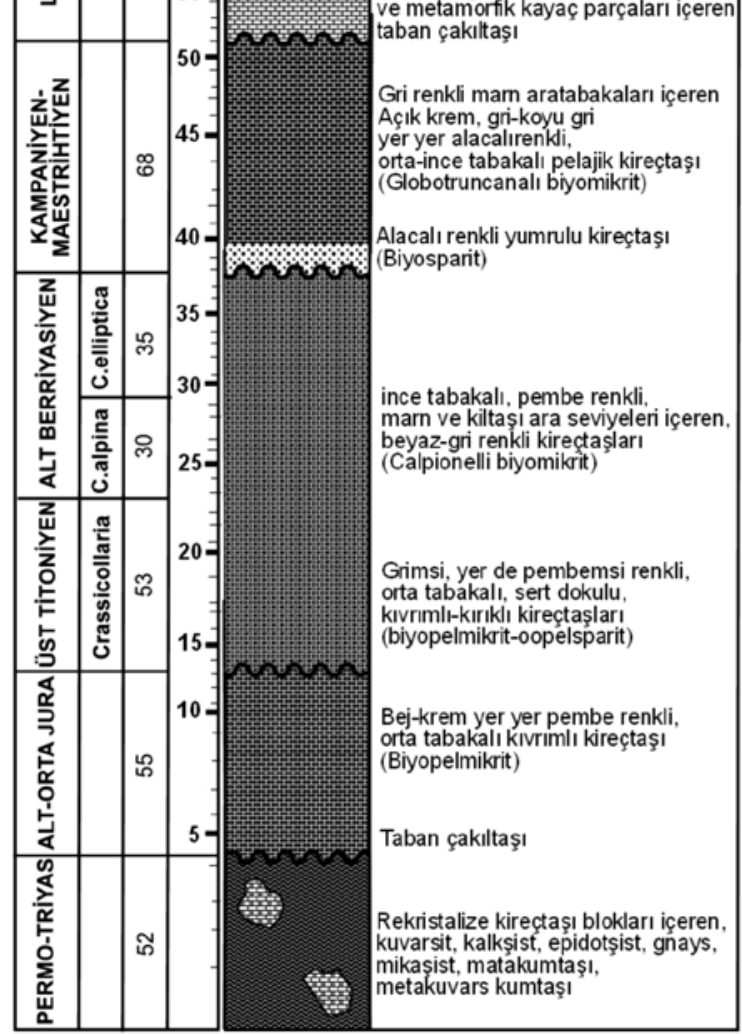

Şekil 7. Sögütözü ölçülü stratigrafi kesiti

Figure 7. Sögütözü measured stratigraphic section

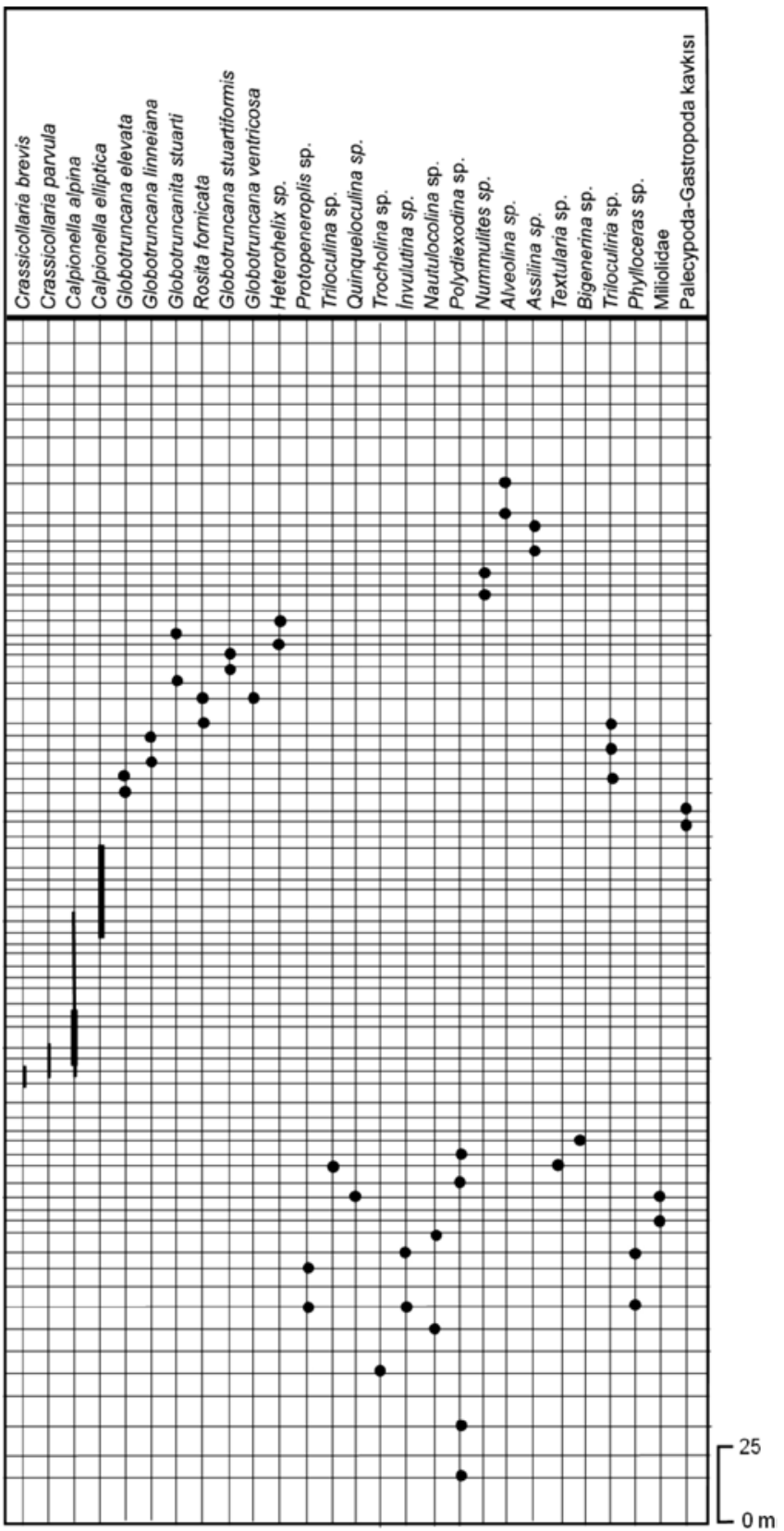


Süleymaniye Ölçülü Stratigrafi Kesiti: İnceleme alanın güneydoğusundaki Süleymaniye köyü kuzeyinden alınan bu kesit, 4457700 enlem, 746850 boylam başlangıç ve 4457740 enlem 745810 boylam bitiş koordinatları arasında, yaklaşık GD-KB yönünde $718 \mathrm{~m}$ gidişlidir. $\mathrm{Bu}$ kesitte toplam $95 \mathrm{~m}$ kalınlık ölçülmüş ve 52 örnek derlenmiştir (Şekil 2).

Kesit alınan yerde tabanda, KampaniyenMaestrihtiyen yaşlı üst düzeylerinde gri renkli marn tabakaları da içeren açık krem, gri-koyu gri yer yer alacalı renkli, ince-orta tabakalı Globotruncanalı biyomikrit mikrobiyofasiyesindeki derin denizel kireçtaşları gözlenmiştir. Bunlar Kampaniyen'de başlayan transgresyonunun ilerleyen evrelerinde hızla derinleşen bölgede gözlenen derin deniz fasiyesinde ki çökellerdir.

Birime ait kireçtaşlarından elde edilen örnekler üzerinde yapılan ayrıntılı paleontoloji çalışmaları sonucunda; Globotruncanita stuarti
(De Lapparent) (Levha I, şekil 16), Rosita fornicata (Plummer), Globotruncana linneiana (D’Orbigny), Globotruncanita stuartiformis Dalbiez, Globotruncana ventricosa White, ve Heterohelix sp. fosilleri saptanmıştır.

Kesit alınan yerde, Lütesiyen transgresyonunun ürünü olan birimler, Kampaniyen-Maestrihtiyen yaşlı birimler üzerine bir taban çakıltaşıyla açılı uyumsuzlukla gelmektedir. Çakıltaşları, kırmızı, alacalı renkli, karbonat çimentolu, ultramafik ve metamorfik kayaç parçaları ile Üst Kretase yaşlı kireçtaşı çakılları içerir. Üste doğru, açık kahve renkli, Nummulitesli biyosparit mikrobiyofasiyeste gelişmiş kumlu kireçtaşların içerisinde, Nummulites sp. (Levha II, şekil 2), Alveolina sp. (Levha II, şekil 4) fosilleri saptanmıştır (Şekil 7).

Lütesiyen yaşlı birimler üzerine uyumsuzlukla Kuvaterner yaşlı birimler gelmektedir.

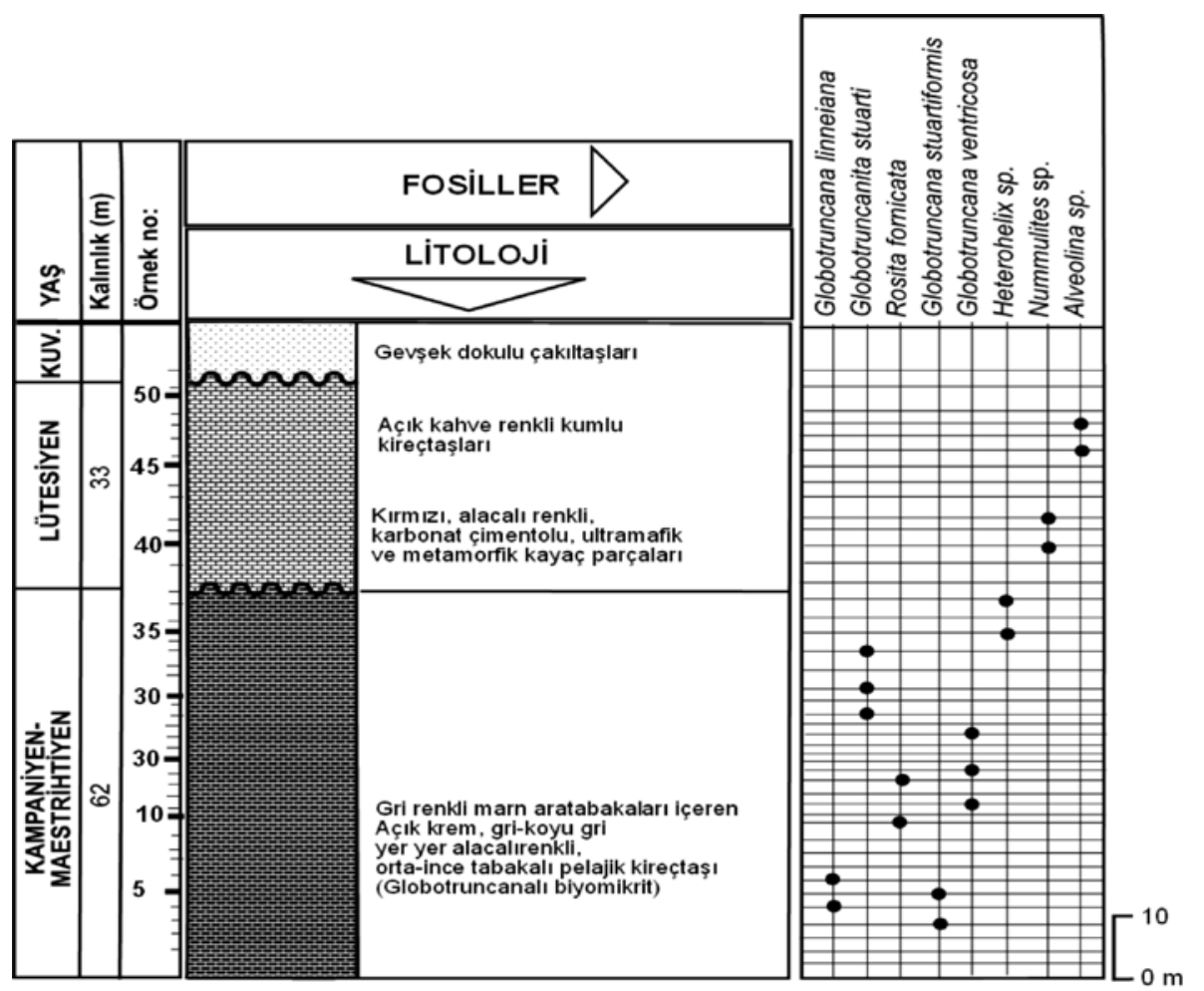

Şekil 8. Süleymaniye ölçülü stratigrafi kesiti

Figure 8. Süleymaniye measured stratigraphic section 


\section{Turhal-Pazar Yöresinin Stratigrafisi}

Turhal yöresinde alüvyonal örtü birimleri ile örtülmüş ve sert durumları nedeniyle aşınmaya karşı dayanımlı olduklarından sert rölyefler oluşturan temel kayaları ve Üst Jura-Alt Kretase yaşı kireçtaşları yüzer durumda bulunmaktadır.

Permo-Triyas: Düşük derecede metamorfizma izleri taşıyan temel kayaları; kuvarsit,kalkşist,epidotşist,milonitgnays,mikaşist, metakumtaşı ve metakuvars kumtaşlarından oluşan metamorfik bir matriks ile bu matriks içerisinde yüzer durumda bulunan rekristalize kireçtaş1/kireçtaşı bloklarından oluşmaktadırlar (Akyazı ve Tunç,1996). Kristalize kireçtaşlanndan alınan örneklerin ince kesitleri üzerinde yapılan çalışmalarda birim içerisinde Permiyen yaşı veren; Schwagerina sp. ve Polydiexodina sp. fosilleri saptanmıştır (Akyazı ve Tunç, 1992). Bu nedenle bu çalışmada da kristalize kireçtaşlarımn yaşı Permiyen olarak kabul edilmiştir. İçerisinde Permiyen yaşlı bloklar bulunduran metamorfik matriksin üzerinde yer alan ve çalışma alanının yakın çevresinde yüzeyleyen Alt-Orta Jura yaşıı Karakese Formasyonu (Özcan, 1980) ile çalışma alanının kuzeybatısında yüzeyleyen Üst JuraAlt Kretase yaşlı Carcurum Formasyonuna ait birimlerin metamorfizma geçirmediği gözönüne alındığında, metamorfitlerinin Permo-Triyas yaşında olduğu ve Üst Jura öncesi metamorfizma geçirdikleri söylenebilir. Birim inceleme alanının ortasında yer alan Turhal ilçesinin kurulduğu ova dışındaki yerlerin tamamına yakın bir alanda geniş yüzlek verirler (Şekil 9, 10).

Baykal (1947) tarafından Paleozoyik Yaşlı Metamorfitler, Blumenthal (1950) tarafından Tokat Kristalin Masifi, Okay (1955) tarafindan Paleozoyik Metamorfitleri, Yılmaz ve diğ., (1995) ve Ketin (1962) tarafindan Tokat Masifi, Seymen (1975) tarafindan Tozanlı Grubu, olarak tanımlanan bu birim, Koçyiğit (1979) tarafından
Tokat Grubu, Yılmaz (1980) tarafından Tokat Formasyonu, Özcan (1980) tarafından Turhal Grubu, Özcan ve diğ., (1980) tarafindan Turhal Metamorfitleri/Devecidağ Karışığı, Gökçe (1983) tarafindan Turhal Metamorfitleri, Şengör ve diğ., (1985) Gölova (Agvanis) Metamorfitleri, Temiz ve diğ., (1993) tarafından Tokat Kompleksi olarak adlandırılan ve tanımlanan Erzincan'dan Amasya'ya kadar uzanan métamorfik zonun bir parçasını oluşturan bu birim Tüysüz, (1993) tarafindan ise, Karakaya Karmaşığı olarak tanımlanmıştır (Çizelge 2).

\section{Üst Titoniyen-Alt Berriyasiyen:}

İnceleme alanındaki Üst Titoniyen-Alt Berriyasiyen yaşlı birimler; düşey ve yanal yönde farklı litofasiyes özelliklerine sahip olup, gel-git ortamından resif önüne hatta derin denizele kadar değişen ortamlarda çökelmiştir. Birim, inceleme alanının Kuzeyinde derin denizel, güneyinde yer alan Pazar ilçesi kuzeyindeki Mercimek Dağ1 yöresinde ise sı̆̆ denizel özellikler göstermektedir (Şekil 9).

Güneyde Mercimek Dağı ve güneydoğuda Çalüstü Tepe dolayında yüzlek veren sı̆g denizel birimler, grimsi, yer de pembemsi renkli, orta tabakal1, biyopelmikrit mikrobiyofasiyeste gelişmiş, konkoidal kırılma yüzeyli, sert, kıvrımlıkırıklı kireçtaşlarından oluşmaktadır. Birime ait örneklerin ince kesitleriyle yapılan incelemeleri sonucunda, Protopeneroplis striata Weynschenk, Triloculina sp, Quinqueloculina sp., Radilaria sp., ve Miliolidae gibi fosiller saptanarak birime Üst Jura-Alt Kretase yaşlı verilmiştir (Şekil 9). İnceleme alanının kuzeyindeki Sırakaya sırtları ve Çengelkaya'da ise, ince tabakalı, pembe renkli marn ve kiltaşı ara düzeyleri içeren, beyaz-gri renkli kireçtaşlarından oluşmaktadır. Calpionelli biyomikrit mikrobiyofasiyesinde gelişmiş olan birimin içerisinde; Üst Titoniyen-Berriyasiyen yaşını veren; Tintinnopsella carpathica 
(Murgeanui \& Filipescu), Tintinnopsella longa (Colom), Crassicollaria intermedia (Durand Delga), Crassicollaria parvula Remane, Crassicollaria brevis Remane, Calpionella alpina Lorenz, Calpionella elliptica Cadisch, Calpionellopsis simplex (Colom), Calpionellopsis oblonga (Cadisch) calpionellerinin yanısira Triloculina sp., Miliolidae, Radiolaria ve sünger spikülleri saptanmıştır (Şekil 10).

Baykal, (1947) tarafindan Ayrılmamış Mesozoyik olarak adlandırılan birim, Blumenthal (1950) Amasya kireçtaşı, Pontid zonu Alt ve Orta Kretase kalkerleri; Altınlı (1971, 1972, 1973) Bilecik kireçtaşları; Alp (1972) CarcurumFerhatkaya Formasyonu; Seymen (1974) Hankırı Tepesi kireçtaş1; Öztürk (1979) Doğdu formasyonu ve Terlemez ve Y1lmaz (1980) tarafindan Zinav kireçtaşı olarak tanımlanan ve adlandırılan birim, Özcan ve diğ., (1980) tarafindan da birbiriyle eşlenik Ferhatkaya, Carcurum, Helvacı ve Karaömer formasyonları olarak Amasya Grubu'na dahil edilmiştir. Ayrıca birim, Gökçe (1983) Buzluk Kireçtaşları; Serdar ve diğ., (1984) Inaltı Formasyonu; Yoldaş ve diğerleri (1985) Belalan kireçtaşı; Akyazı (1996) Sarıalan formasyonu olarak tanımlanmış ve adlandırılmıştır (Şekil 13)

Kuvaterner: Çalışma alanının en genç birimleri, Deliçay, Çivrilözü, Çarıklı, Kayalıca ve Özbaş derelerinin beslediği Yeşilırmak getirimlerinin oluşturduğu Turhal düzlüğü ve Kazovayı kapsayan geniş düzlüklerde yer alan Kuvaterner yaşlı alüvyonlardır (Şekil 9). 


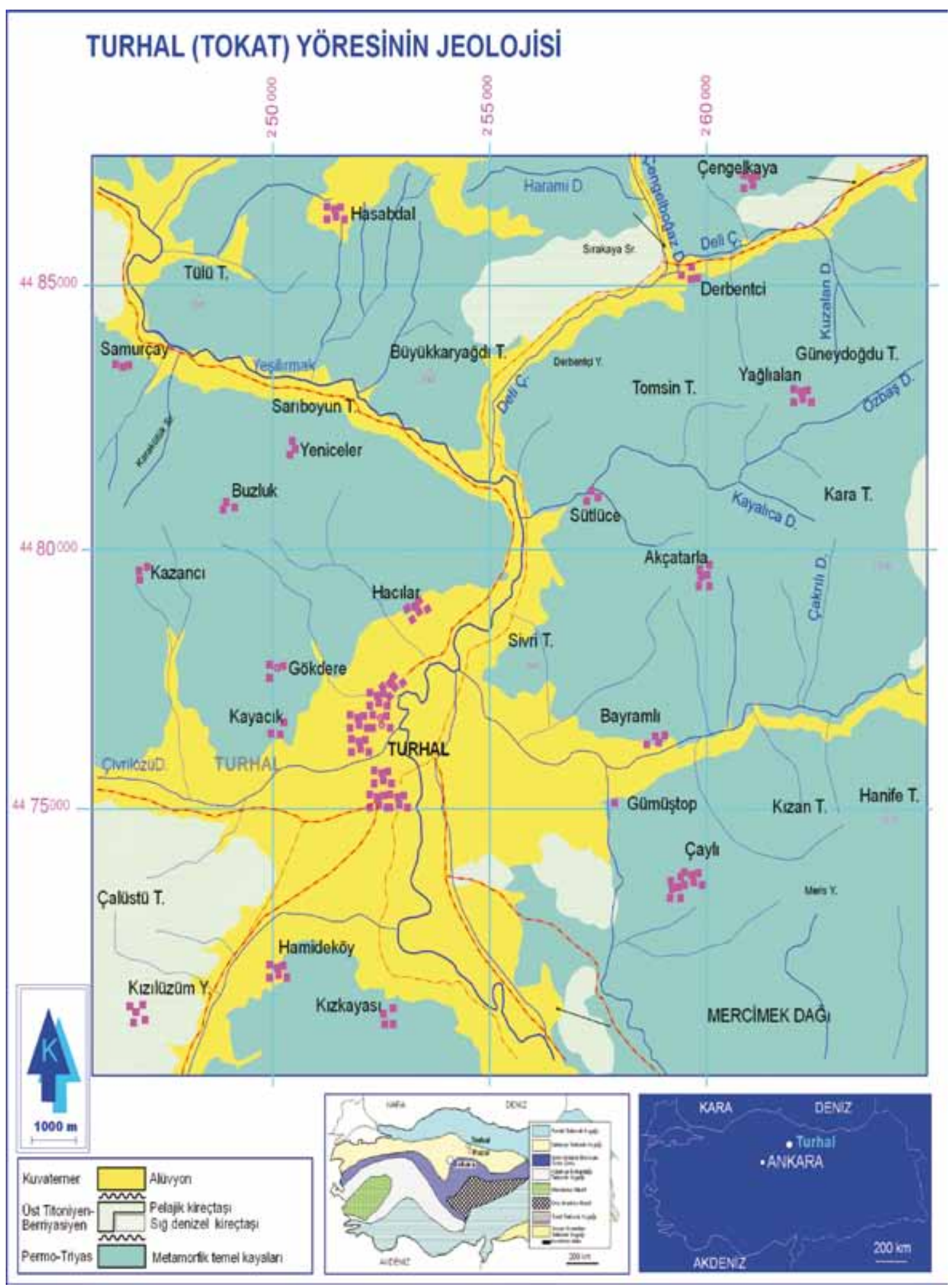

Şekil 9. Turhal-Pazar yöresinin jeoloji haritası

Figure 9. The geological map of Turhal-Pazar region 


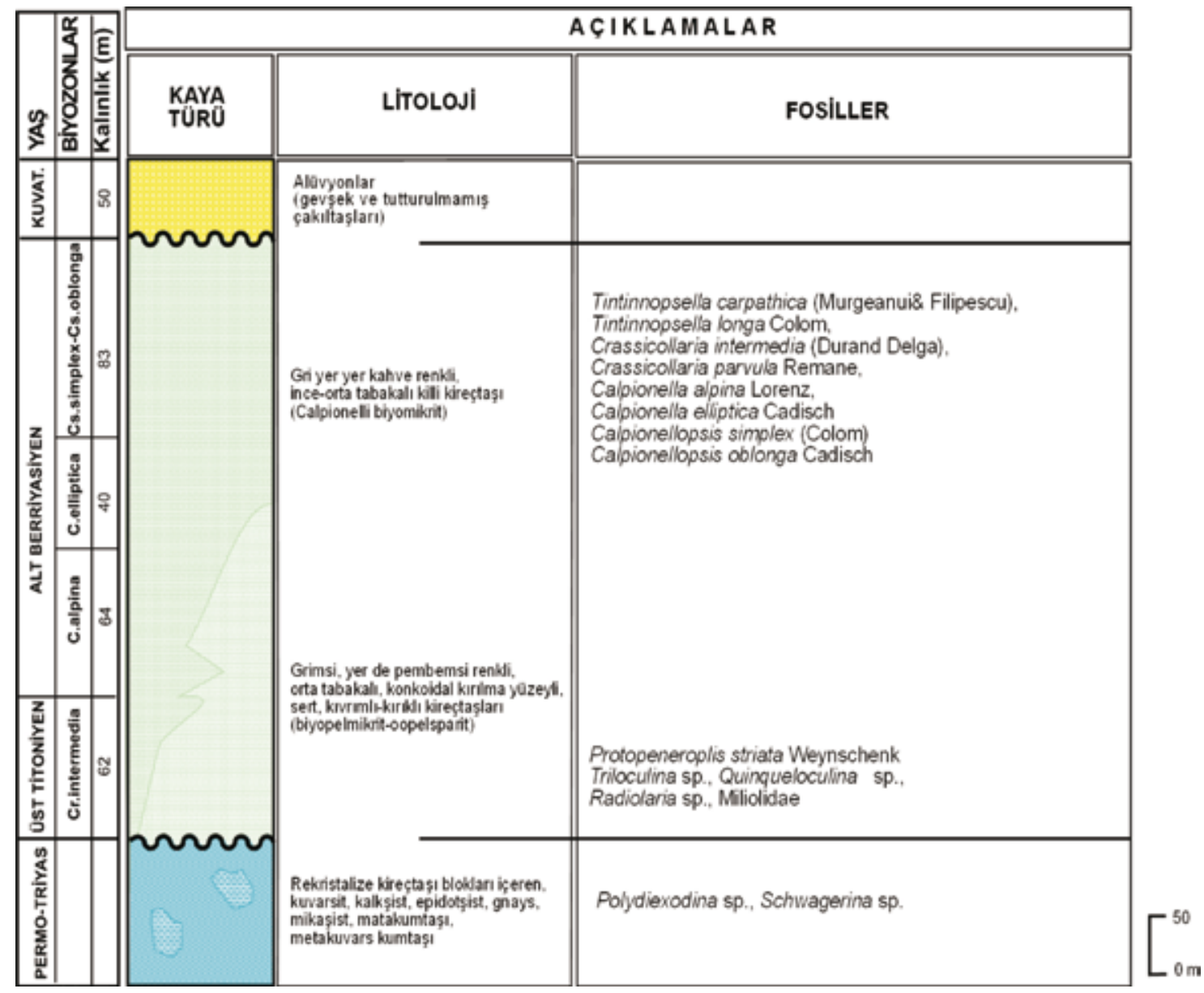

Şekil 10. Turhal-Pazar yöresinin stratigrafi kesiti

Figure 10. The stratigraphic section of Turhal-Pazar region

\section{Pazar Yöresi Ölçülü Stratigrafi Kesitleri}

\section{Mercimek Dağı Ölçülü Stratigrafi Kesiti:}

İnceleme alanın güneyinde yer alan Pazar İlçesinin kuzeyndeki Mercimek Dağının batısından başlanarak yaklaşık GD-KB dpğrultusunda alınan bu kesit, 4470600 enlem, 258810 boylam başlangıç ve 4470950 enlem 256300 boylam bitiş koordinatları arasında $1105 \mathrm{~m}$ gidişlidir. Kesitte toplam $124 \mathrm{~m}$ kalınlık ölçülmüş ve 32 örnek derlenmiştir (Şekil 10).

Kesitalınan yerde tabanda, düşük derecede metamorfızma izleri taşıyan temel kayaları yer almaktadır. Permo-Triyas yaşı bu birim; kuvarsit, kalkşist, epidotşist, milonitgnays, mikaşist, metakumtaşı ve metakuvars kumtaşlarından oluşan metamorfik bir matriks ile bu matriks içerisinde yüzer durumda bulunan rekristalize kireçtaş1/kireçtaş1 bloklarından oluşmakta olup kireçtaşı blokları içerisinde Schwagerina sp. ve Polydiexodina sp. fosilleri saptanmıştır.

Permo-Triyas yaşlı birimler üzerine uyumsuzlukla gelen Üst Jura-Alt Kretase yaşlı birimler, grimsi, yer de pembemsi renkli, orta tabakal1, biyopelmikrit mikrobiyofasiyeste gelişmiş konkoidal kırılma yüzeyli, sert, kıvrıml1-kırıklı kireçtaşlarından oluşmaktadır. Birime ait örneklerin ince kesitleriyle yapılan 
incelemeleri sonucunda, Protopeneroplis striata Weynschenk (Levha III, şekil 4), Triloculina sp,, Quinqueloculina sp., Radiolaria sp., ve Miliolidae gibi fosiller saptanarak birime Üst Jura-Alt Kretase yaşlı verilmiştir.
Kesit alınan yerdeki en genç birimler, Yeşilırmak getirimlerinin oluşturduğu Turhal ovası ve Kazovayı kapsayan geniş düzlüklerde yer alan Kuvaterner yaşlı alüvyonlardır (Şekil 11).

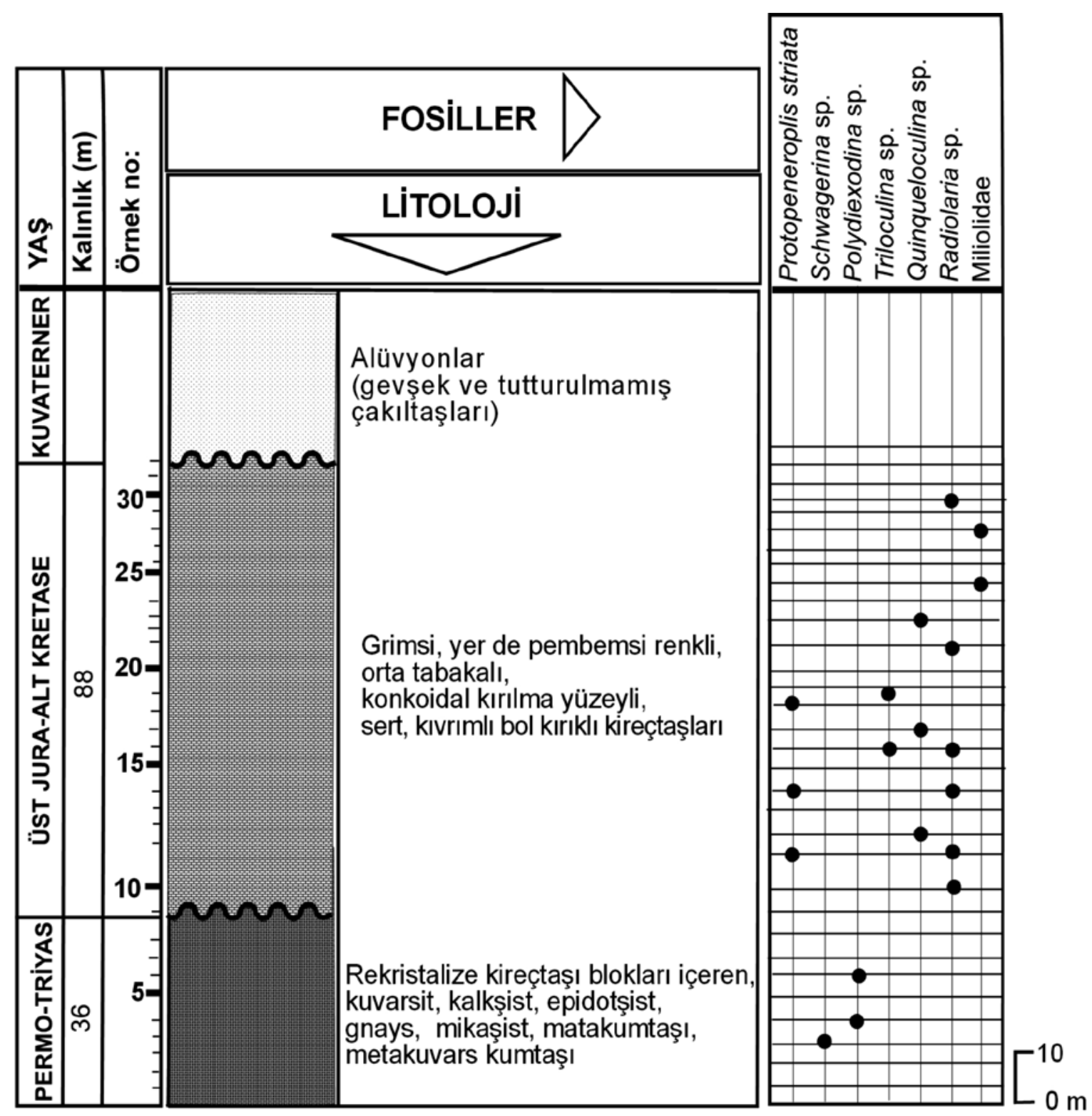

Şekil 11. Mercimekdağı ölçülü stratigrafi kesiti

Figure 11. Mercimekdağı measured stratigraphic section 
Turhal-Çengelkaya Yöresi Ölçülü Stratigrafi Kesitleri

Çengelkaya Ölçülü Stratigrafi Kesiti: İnceleme alanın kuzeyinde yeralan Çengelkayanın doğusundan başlanarak alınan bu kesit, 4487050 enlem, 262350 boylam başlangıç ve 4486980 enlem 263050 boylam bitiş koordinatları arasında, yaklaşık B-D doğrultusunda 987 m gidişlidir. Bu kesitte toplam 196 m kalınlık ölçülmüş ve 37 örnek derlenmiştir (Şekil 11).

Kesit alınan yerde tabanda, düşük derecede metamorfizma izleri taşıyan temel kayaları yer almaktadır. Permo-Triyas yaşlı bu birim; metamorfik bir matriks ile bu matriks içerisinde yüzer durumda bulunan rekristalize kireçtaş1/kireçtaşı bloklarından oluşmaktadır.

Temel kayalarının üzerinde uyumsuz olarak yer alan Üst Tithoniyen-Berriyasiyen yaşlı birim; ince tabakalı, pembe renkli marn ve kiltaşı ara düzeyleri içeren, Calpionelli biyomikrit mikrobiyofasiyesinde gelişmiş beyaz-gri renkli kireçtaşlarından oluşmaktadır.

Üst Tithoniyen-Berriyasiyen yaşl1 birimin Üst Tithoniyen yaşlı düzeyleri içerisinde; Crassicollaria intermedia (Durand Delga) (Levha I, şekil 3), Crassicollaria parvula Remane, Calpionella alpina Lorenz ve Radiolarialar saptanmış ve yapılan biyostratigrafik çalışmalarla Crassicollaria intermedia Calpionel biyozonu tanımlanmıştır.

Birimin Alt Berriyasiyen yaşlı düzeyleri içerisinde; Crassicollaria parvula Remane, Calpionella alpina Lorenz, (Levha I, şekil 9; Levha II, şekil 1) Calpionella elliptica Cadisch, radiolaria ve sünger spikülleri saptanmış ve yapılan biyostratigrafik çalışmalarla Calpionella alpina, Calpionella elliptica Calpionel biyozonları tanımlanmıştır (Şekil 3).
Birimin Üst Berriyasiyen yaşl düzeylerinde Tintinnopsella longa (Colom) (Levha I, şekil 2), Calpionellopsis simplex (Colom), Calpionellopsis oblonga (Cadisch) (Levha I, şekil 14) radiolaria ve sünger spikülleri saptanmış, yapılan biyostratigrafik çalışmalarla Calpionellopsis simplex-Calpionellopsis oblonga Calpionel biyozonu tanımlanmıştır (Şekil 3).

Kesit alınan yerdeki en genç birimler, Yeşilırmak getirimlerinin oluşturduğu Turhal düzlüğü ve Kazovayı kapsayan geniş düzlüklerde yer alan Kuvaterner yaşlı alüvyonlardır.

Sırakayalar Ölçülü Stratigrafi Kesiti: İnceleme alanın kuzeyinde yeralan Sirakayalardan başlayarak, Çengelboğazı Dereye kadar alınan bu kesit, 4486100 enlem, 258810 boylam başlangıç ve 4485450 enlem 258980 boylam bitiş koordinatları arasında, yaklaşık KB-GD yönünde $970 \mathrm{~m}$ gidişlidir. Bu kesitte toplam $321 \mathrm{~m}$ kalınlık ölçülmüş ve 42 örnek derlenmiştir.

Kesit alınan yerde tabanda, düşük derecede metamorfizma izleri taşıyan temel kayaları yer almaktadır. Permo-Triyas yaşı bu birim; metamorfik bir matriks ile bu matriks içerisinde yüzer durumda bulunan rekristalize kireçtaş1/kireçtaşı bloklarından oluşmakta olup kireçtaşı blokları içerisinde Schwagerina sp. (Levha III, şekil 3) fosili saptanmıştır (Şekil 12).

Temel kayalarının üzerinde uyumsuz olarak yer alan Üst Tithoniyen-Berriyasiyen yaşlı birim; ince tabakalı, pembe renkli marn ve kiltaşı ara düzeyleri içeren, Calpionelli biyomikrit mikrobiyofasiyesinde gelişmiş beyaz-gri renkli kireçtaşlarından oluşmaktadır. Birimin Üst Tithoniyen yaşlı düzeyleri içerisinde; Tintinnopsella carpathica (Murgeanui \& Filipescu), Crassicollaria intermedia (Durand Delga), Crassicollaria parvula Remane fosilleri saptanmış ve yapılan biyostratigrafik çalışmalarla 
Crassicollaria intermedia Calpionel biyozonu tanımlanmıştır.

Birimin Alt Berriyasiyen yaşlı düzeyleri içerisinde; Tintinnopsella carpathica (Murgeanui \& Filipescu) (Levha I, şekil 1), Calpionella alpina Lorenz, Calpionella elliptica Cadisch (Levha I, şekil 12) fosilleri saptanmış ve yapılan biyostratigrafik çalışmalarla Calpionella alpina, Calpionella elliptica Calpionel biyozonları tanımlanmıştır (Şekil 12).
Birimin Üst Berriyasiyen yaşlı düzeylerinde, Tintinnopsella longa (Colom), Calpionellaalpina Lorenz, Calpionellopsissimplex (Colom) (Levha I, şekil 13), Calpionellopsis oblonga (Cadisch) radiolaria ve sünger spikülleri saptanmış, yapılan biyostratigrafik çalışmalarla Calpionellopsis simplex-Calpionellopsis oblonga Calpionel biyozonu tanımlanmıştır (Şekil 12). Kesit alınan yerdeki en genç birimler, geniş düzlüklerde yer alan Kuvaterner yaşlı alüvyonlardır.

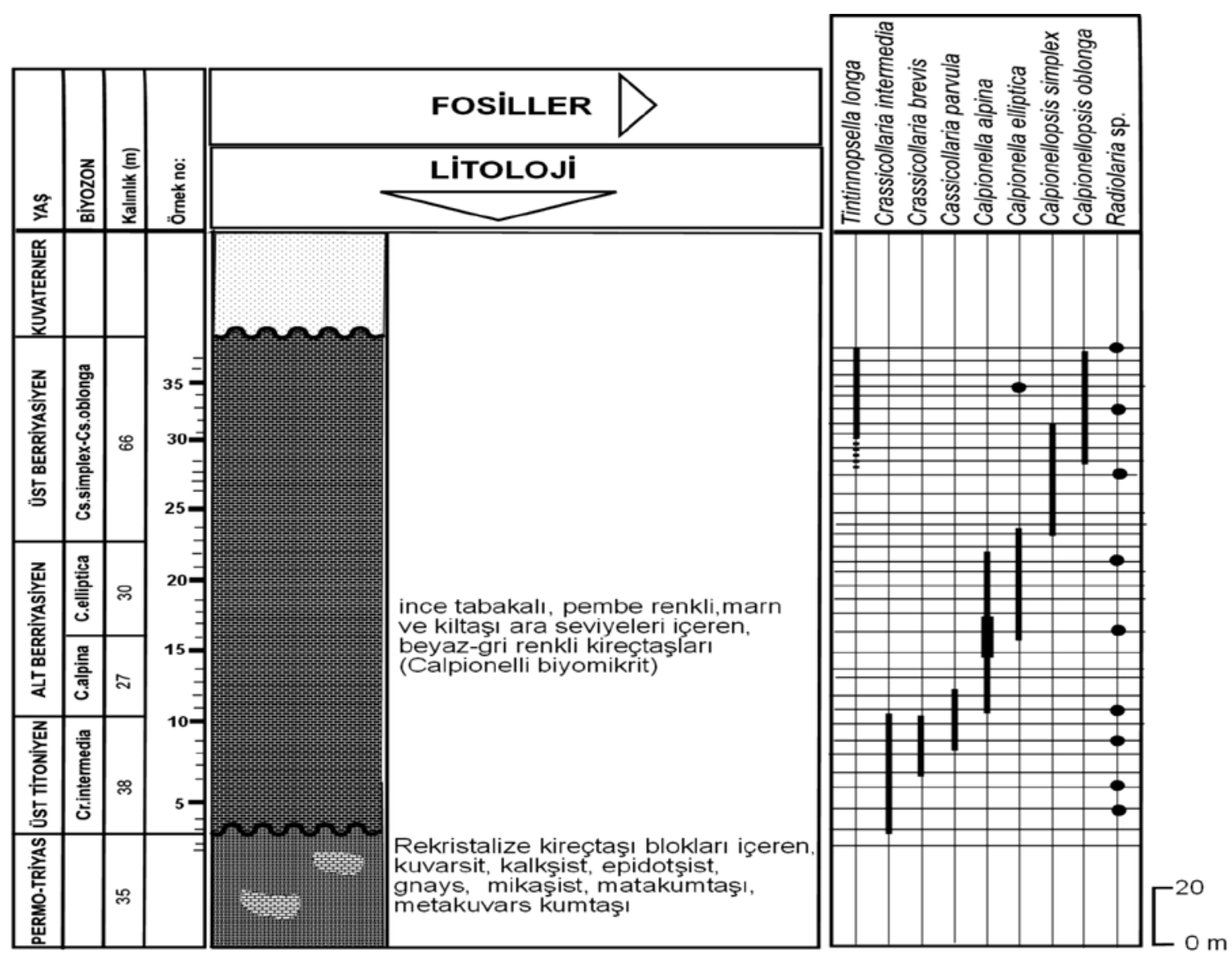

Şekil 12. Çengelkaya ölçülü stratigrafi kesiti

Figure 12. Çengelkaya measured stratigraphic section 


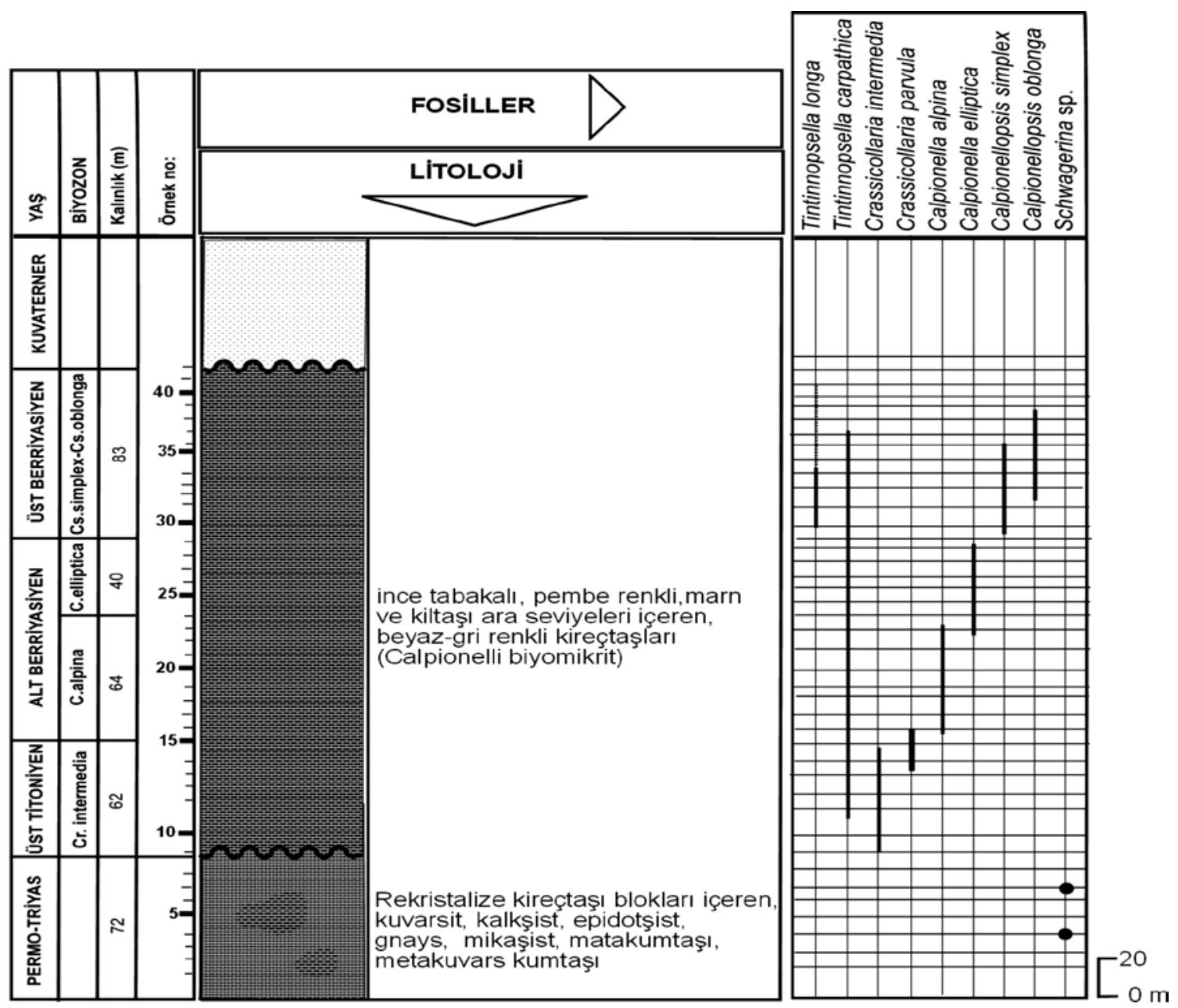

Şekil 13. Sırakayalar ölçülü stratigrafi kesiti

Figure 13. Sirakayalar measured stratigraphic section

\section{MORFOLOJI}

Yörenin genel morfolojisini, Paleozoyik yaşlı temel karmaşı̆̆ının ve Jura-Kretase yaşlı rekristalize kireçtaşlarının rölyefli durumu belirlemektedir. Örtü birimlerinde gözlenen düşük ölçekli kıvrımlar, kırılmalar, sürüklenim ve bindirmeler bugünkü morfolojiyi yansitmakta olup, Hersiniyen ve Alpin Oraojenik hareketleri ile gelişmiştir. Permo-Triyas yaşı metamorfitlerinden sonraki dönemlerde oluşmuş birimlerde metamorfizma etkisinin görülmeyişi, metamorfizmanın, Hersiniyen dağ oluşum evresinde gelişmiş olduğunu göstermektedir.
İnceleme alanı, Türkiye'nin coğrafya bölgelerinden Karadeniz bölgesinin Orta Karadeniz bölümüne rastlar ve İç Anadolu Bölgesi ile Orta Karadeniz bölümünün sınırında bulunur. Burada, coğrafya yönünden her iki bölgenin özelliklerine rastlanır. Bölgenin geneli geniş düzlüklerden oluşmakta olup, litolojik yapı morfolojiye yansımıştır. Doruklar Jura-Kretase yaşlı sert kireçtaşları ve Permo-Triyas yaşlı Metamorfitlerden oluşan sert morfoloji dişında "yaşlı dağ" tipinde, inceleme alanının kuzeyinde ve güneyinde doğu-batı gidişli orta yükseklikteki sirtlar halindedir. 


\section{PALEONTOLOJI}

Çalışmanın gerçekleştirildiği Turhal-PazarZile (Tokat) yöresinde Globotruncana sp., Globotruncanita sp. ve Rosita sp. cinslerine ait 6 adet pelajik foraminifer türü ile Tintinnopsella, Crassicollaria, Calpionella, Calpionellopsis cinsleri ve bu cinslere ait; Tintinnopsella longa (Colom), Tintinnopsella carpathica (Murgeanui \& Filipescu), Crassicollaria brevis Remane, Crassicollaria parvula Remane, Calpionella alpina Lorenz, Calpionella elliptica Cadisch, Calpionellopsis simplex (Colom), Calpionellopsis oblonga Cadisch türleri saptanmış ve Calpionel biyostratigrafisine yönelik çalışmalar yapılmıştır (Çizelge 1).

\section{CALPIONEL BIYYOSTRATIGRAFISI}

Yurdumuzun ve dünyanın birçok yöresinde JuraKretase geçişi, tortullaşmanın devamlı oluşu nedeniyle litolojik olarak ayırt edilememektedir. Titoniyen katının bir ürünü olan ve 'Titonik Fasiyes' olarak tanımlanan ince tabakanın pelajik kireçtaşları içerisinde bol olarak bulunan calpionellidler, tetis provensi içerisinde, çok geniş coğrafik yayılıma sahip olmaları ve geç TitoniyenBerriyasiyen zaman aralığındaki herhangi bir mikro veya nannofosil gruplarından daha kararlı olmaları nedeni ile çok önemlidirler. Tetis Provensi içerisinde yer alan Türkiye'de, Tunç, 1979,1991 (Ankara): Tunç, 1980 (Bolu): Önal ve diğ. 1988: Koçyiğit ve diğ., 1991: Altıner ve Özkan, 1991: Altıner ve diğ., 1993: Özkan,1993: Mekik ve diğ.,1998 (KB Anadolu): Tunç,1992 a-b (Erzurum): Burşuk,1981,1992: Tunç ve Akyaz1,2000 (Bayburt): Akyaz1,1996: Akyaz1 ve Özgen, 1996: Akyazı ve Tunç,1998 (Ilgaz) Calpionellid Biyostratigrafisine yönelik olarak yapılan bu çalışmalar, oldukça önemli ve dikkat çekicidir.

\section{Turhal- Çengelkaya yöresinin Calpionel Biyostratigrafisi}

Çalışmada, Geç Titoniyen-Berriyasiyen yaşlı, ince tabakalı, pembe renkli marn ve kiltaşı ara düzeyleri içeren, beyaz-gri renkli kireçtaşlarından oluşmaktadır. Calpionelli biyomikrit mikrobiyofasiyesinde gelişmiş olan kireçtaşları üzerinde yapılan biyostratigrafik incelemelerden elde edilen veriler 1şığında, 4 adet calpionel biyozonu ayırtlanmıştır (Çizelge 1).

\section{Crassicollarla İntermedia Biyozonu}

Tanım: Crassicollaria intermedia (Durand Delga)'nın yaşam süresinde oluşmuş kayaçlar

Türü: Menzil zonu

Zonu tanımlayan: Catalano \& Liguari (1970)

Kalınlık: 38-62 m

Stratigrafik düzey: Geç Titoniyen

Fosil topluluğu: Tintinnopsella carpathica (Murgeanui ve Filipescu), Crassicollaria Intermedia (Durand Delga), Crassicollaria parvula Remane ve Crassicollaria brevis Remane

Karşılaştırma: Burşuk (1992), Mekik ve diğ (1998), Akyazı ve Tunç (1998) tarafından tanımlanan Crassicollaria İntermedia zonuna, Tunç ve Akyazı (2000) tarafindan tanımlanan Crassicollaria intermedia zonunun üst ve Calpionella alpina zonuna ait düzeylerine karşıl1k gelen bu biyozon, 1970 Roma standartları zonundan 'Crassicollaria' zonuna karşılıktır.

Tanımlanan bu zonun tabanı, çok küçük boyutlu olan ve yakaları genellikle kaybolmuş Tintinnopsellacarpathica(MurgeanuiveFilipescu) ile Crassicollaria intermedia (Durand Delga)'nın ortaya çıktığı döneme karşılık gelmektedir. Üste doğru Crassicollaria Intermedia (Durand 
Delga)'nın sayısal artışı göze çarpmaktadır. Daha sonra ise; iri boyutlu Calpionella alpina Lorenz'nın ortaya çıktığ 1 ve çoğaldı ğı gözlenmektedir. Zonun üst kısımlarında ise, Crassicollaria brevis Remane ve Crassicollaria parvula Remane'nin ortaya çıktıkları ve baskın duruma geçtikleri gözlenir (Çizelge 3).

\section{Calpionella alpina Biyozonu}

Tanım: Crassicollaria intermedia (Durand Delga)'nın yok oluşu ile Calpionella elliptica Cadisch'nin ortaya çıkışı arasındaki süreçte oluşan kayaçlarla temsil edilip, aynı zamanda küçük boyutlu, sferik Calpionella alpina Lorenz'ların ortaya çıkışı ve maksimum bolluğa ulaşması ile karakteristiktir.

Türü: Aşmalı menzil zonu veya bolluk zonu

Zonu tanımlayan: Catalano ve Liguari

Kalınlık: 27-64 m.

Stratigrafik düzey: Erken Berriyasiyen'in altı

Fosil Topluluğu: Calpionella alpina Lorenz, Crassicollaria parvula Remane, Tintinnopsella carpathica (Murgeanui ve Filipescu).

Karşılaştırma: Biyozon, Roma standart zonlarında calpionella zonunun alt bölümüne karşılık gelmektedir. Burşuk(1992), Akyazı ve Tunç (1998) tarafindan tanımlanan Calpionella alpina zonuna karşı1lık gelen bu zon, Tunç (1980,1991) Calpionella elliptica zonunun ve Mekik ve diğ.(1998) Calpionella B zonunun alt düzeylerine, Tunç ve Akyazı (2000) Calpionella alpina zonunun ise üst düzeylerine karşı1lık gelmektedir (Çizelge 3).

\section{Calpionella elliptica Biyozonu}

Tanım: Calpionella elliptica Cadisch'in ortaya çıkışı ile Calpionellopsis simplex (Colom)'in ortaya çıkışı arasındaki süreçte oluşan kayaçlarla temsil edilir.

Türü: Aşmalı menzil zonu

Zonu Tanımlayan: Catalano ve Liguari (1970)

Kalınlık: $30-40$ m.

Stratigrafik düzey: Berriyasiyen' in üstü

Fosil Topluluğu: Tintinopsella Carpathica (Murgeanui ve Filipescu), Calpionella alpina Lorenz ve Calpionella elliptica Cadisch

Karşılaştırma: Roma standart zonlarında Calpionella zonu üst düzeylerine ve Burşuk (1992), Akyazı ve Tunç (1998), Tunç ve Akyazı (2000) Calpionella elliptica zonuna karşılık gelen bu zon, Tunç, (1980,1991) Calpionella elliptica zonunun Mekik ve diğ. (1998) Calpionella B zonunun üst düzeylerine karşılık gelmektedir (Çizelge 3).

\section{Calpionellopsis simplex-Calpionellopsis oblonga Biyozonu}

Tanım: Calpionellopsis simplex (Colom)' in ortaya çıktığ 1 , Calpionellopsis oblonga (Cadisch)'nın ve Tintinnopsella longa (Colom)'un görüldügü yer arasında oluşan kayaçlarla temsil edilir.

Türü: Aşmalı menzil zonu

Zonu tanımlayan: Catalano ve Liguari (1970)

Kalınlık: $66-83$ m.

Stratigrafik düzey: Geç Berriyasiyen

Fosil Topluluğu: Tintinnopsella carpathica (Murgeanui ve Filipescu), Tintinnopsella longa(Colom) Calpionellopsis Simplex (Colom), Calpionellopsis oblonga 
(Cadisch) ve zonun tabanında az sayıda Calpionella elliptica Cadisch

Karşılaştırma: Roma standart zonlarında Calpionellopsis zonunun Valinjiniyen'e kadar olan bölümüne karşılık gelen bu biyozon, Burşuk (1992), Tunç (1980,1991), Akyazı ve Tunç (1998) tarafindan tanımlanan Calpionellopsis simplexCalpionellopsis oblonga biyozonuna karşı1lık gelmektedir (Çizelge 1) çıktıkları ve baskın duruma geçtikleri, daha sonra ise; iri boyutlu Calpionella alpina Lorenz'nın ortaya çıktığı ve çoğaldığı gözlenmektedir (Çizelge 2).

Türü: Menzil zonu

Zonu tanımlayan: Catalano \& Liguari

Kalınlık: 40-53 m

Stratigrafik düzey: Geç Titoniyen

Çizelge 1. Turhal yöresinde tanımlanan calpionellerin stratigrafik dağılımı ve Calpionel biyozonları

Table 1. Calpionellid biozones and stratigraphic distribution of calpionellids in Turhal region

\begin{tabular}{|c|c|c|c|c|c|}
\hline \multirow{2}{*}{\multicolumn{2}{|c|}{$\begin{array}{l}\text { KATLAR } \\
\text { BIYYZONLAR }\end{array}$}} & \multirow{2}{*}{$\begin{array}{c}\text { ÜST TiTONIYEN } \\
\text { Cr.intermedia }\end{array}$} & \multicolumn{2}{|c|}{ ALT BERRIYASIYEN } & \multirow{2}{*}{$\begin{array}{l}\text { ÜST BERRIYASIYEN } \\
\text { Cs.simplex-Cs.oblonga }\end{array}$} \\
\hline & & & C.alpina & C.elliptica & \\
\hline \multirow{6}{*}{ 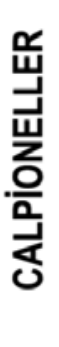 } & \multirow{6}{*}{$\begin{array}{l}\text { Tintinnopsella carpathica } \\
\text { Tintinnopsella longa } \\
\text { Crassicollaria intermedia } \\
\text { Crassicollaria brevis } \\
\text { Crassicollaria parvula } \\
\text { Calpionella alpina } \\
\text { Calpionella elliptica } \\
\text { Calpionellopsis simplex } \\
\text { Calpionellopsis oblonga }\end{array}$} & & & & \\
\hline & & & & & \\
\hline & & & & & \\
\hline & & & $-\cdots \cdot \cdot$ & & \\
\hline & & & & & $\cdots$ \\
\hline & & & & & \\
\hline
\end{tabular}

\section{Zile yöresinin Calpionel Biyostratigrafisi}

Çalışmada, Geç Titoniyen-Erken Berriyasiyen yaşlı, ince tabakalı, pembe renkli marn ve kiltaşı ara düzeyleri içeren, beyaz-gri renkli kireçtaşlarından oluşmaktadır. Calpionelli biyomikrit mikrobiyofasiyesinde gelişmiş olan kireçtaşları üzerinde yapılan biyostratigrafik incelemelerden elde edilen veriler ışı ğında, 3 adet calpionel biyozonu ayırtlanmıştır (Çizelge 2).

\section{Crassicollarla Biyozonu}

Tanım: Crassicollaria parvula Remane ve Crassicollaria brevis Remane'nin yaşam süresinde oluşmuş kayaçlar. Crassicollaria brevis Remane ve Crassicollaria parvula Remane'nin ortaya
Fosil topluluğu: Crassicollaria parvula Remane ve Crassicollaria brevis Remane ve Calpionella alpina Lorenz

Karşılaştırma: Burşuk (1992), Mekik ve diğ (1998), Akyazı ve Tunç (1998) tarafından tanımlanan Crassicollaria İntermedia zonuna, Tunç ve Akyazı (2000) tarafindan tanımlanan Crassicollaria intermedia zonunun üst ve Calpionella alpina zonuna ait düzeylerine karşıllk gelen bu biyozon, 1970 Roma standartları zonundan 'Crassicollaria' zonuna karşılıktır (Çizelge 3).

\section{Calpionella alpina Biyozonu}

Tanım: Küçük boyutlu, sferik Calpionella alpina Lorenz'ların ortaya çıkışı ve maksimum bolluğa 
ulaşması ile Calpionella elliptica Cadisch'nin ortaya çıkışı arasındaki süreç (Çizelge 3).

Türü: Aşmalı menzil zonu veya bolluk zonu

Zonu tanımlayan: Catalano ve Liguari (1970)

Kalınlık: $22-30$ m.

Stratigrafik düzey: Erken Berriyasiyen'in altı

Fosil Topluluğu: Calpionella alpina Lorenz, Crassicollaria parvula Remane, Tintinnopsella carpathica (Murgeanui ve Filipescu).

Karşılaştırma: Biyozon, Roma standart zonlarında calpionella zonunun alt bölümüne karşılık gelmektedir. Burşuk(1992), Akyazı ve Tunç (1998) tarafından tanımlanan Calpionella alpina zonuna karşılık gelen bu zon, Tunç (1980,1991) Calpionella elliptica zonunun ve Mekik ve diğ.(1998) Calpionella B zonunun alt düzeylerine, Tunç ve Akyazı (2000) Calpionella alpina zonunun ise üst düzeylerine karşıllk gelmektedir (Çizelge 3).

\section{Calpionella elliptica Biyozonu}

Tanım: Calpionella elliptica Cadisch'in ortaya çıkışı bol olduuğu süreçte oluşan kayaçlarla temsil edilir.

Türü: Aşmalı menzil zonu

Zonu Tanımlayan: Catalano ve Liguari (1970)

Kalınlık: 27-35 m.

Stratigrafik düzey: Berriyasiyen'in üstü

Fosil Topluluğu: Calpionella alpina Lorenz ve Calpionella elliptica Cadisch

Karşılaştırma: Roma standart zonlarında Calpionella zonu üst düzeylerine ve Burşuk (1992), Akyazı ve Tunç (1998), Tunç ve Akyazı (2000) Calpionella elliptica zonuna karş1lık gelen bu zon, Tunç, (1980,1991) Calpionella elliptica zonunun Mekik ve diğ. (1998) Calpionella B zonunun üst düzeylerine karşılık gelmektedir (Çizelge 3).

Çizelge 2. Zile yöresinde tanımlanan calpionellerin stratigrafik dağılımı ve Calpionel biyozonları

Table 2. Calpionellid biozones and stratigraphic distribution of calpionellids in Zile region

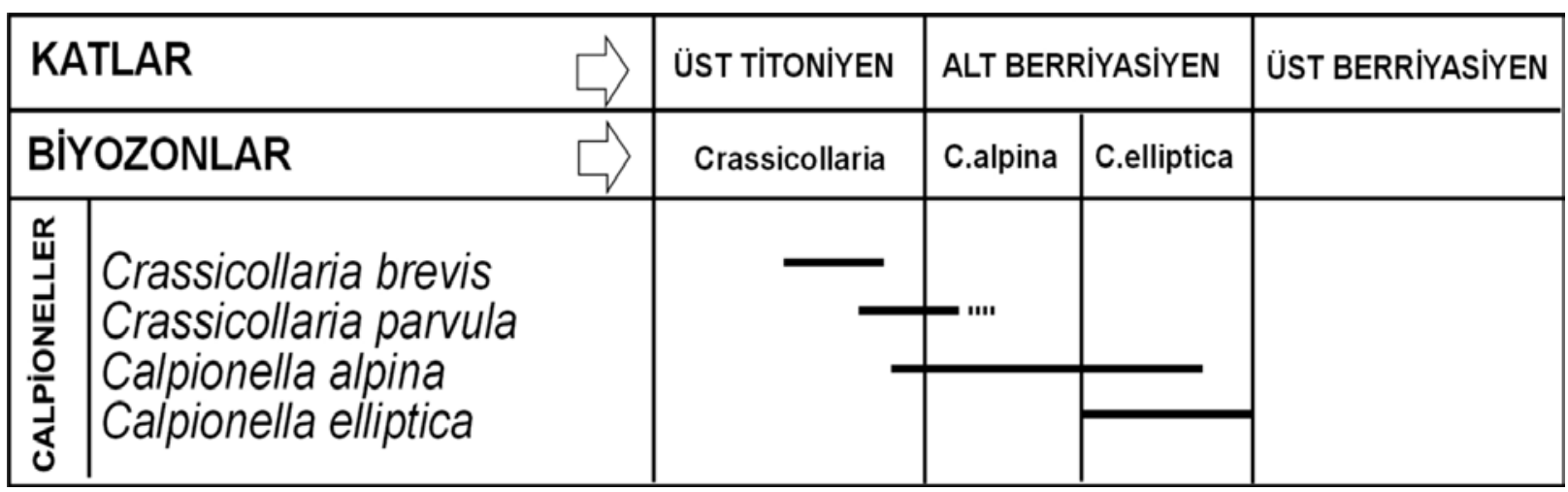




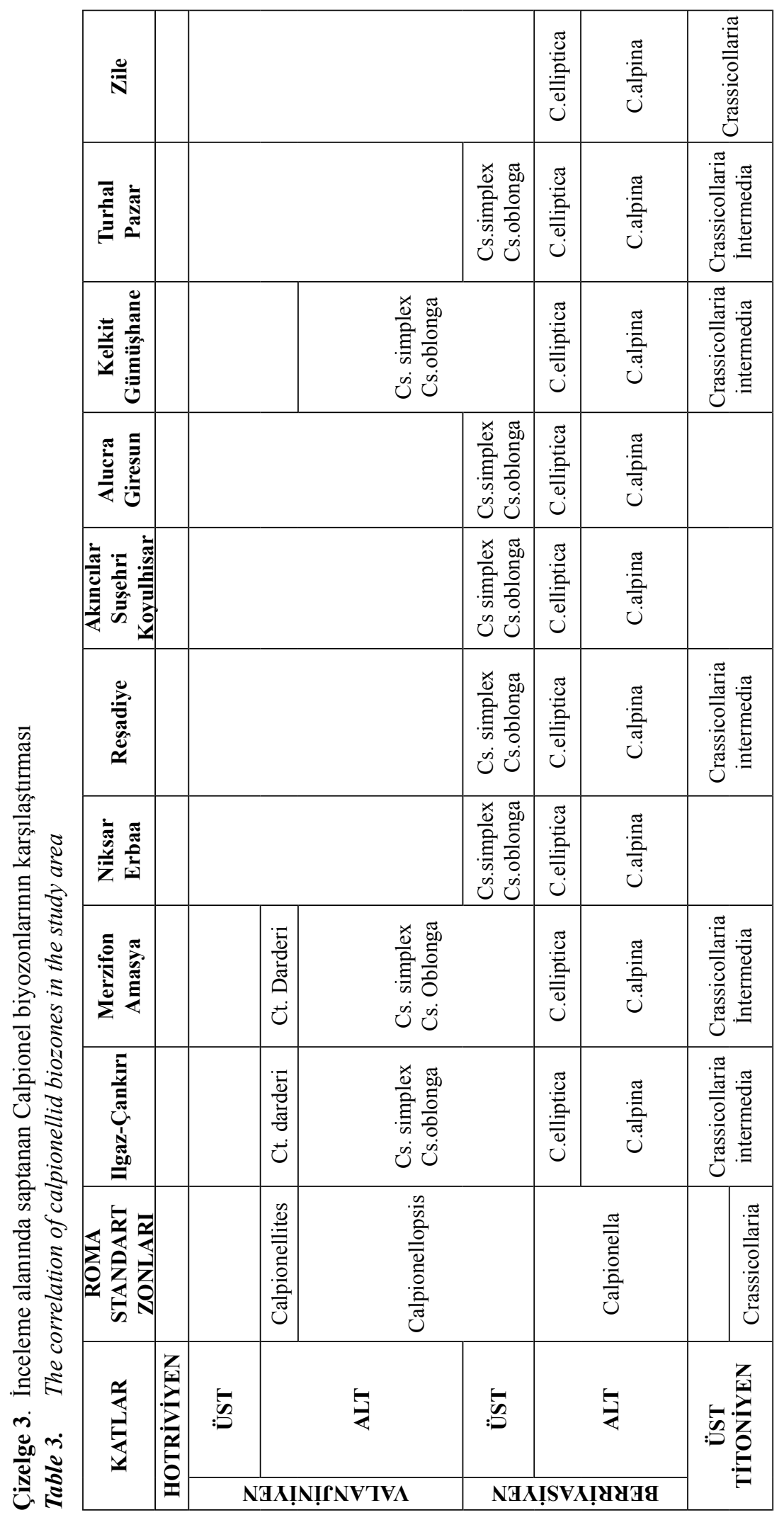




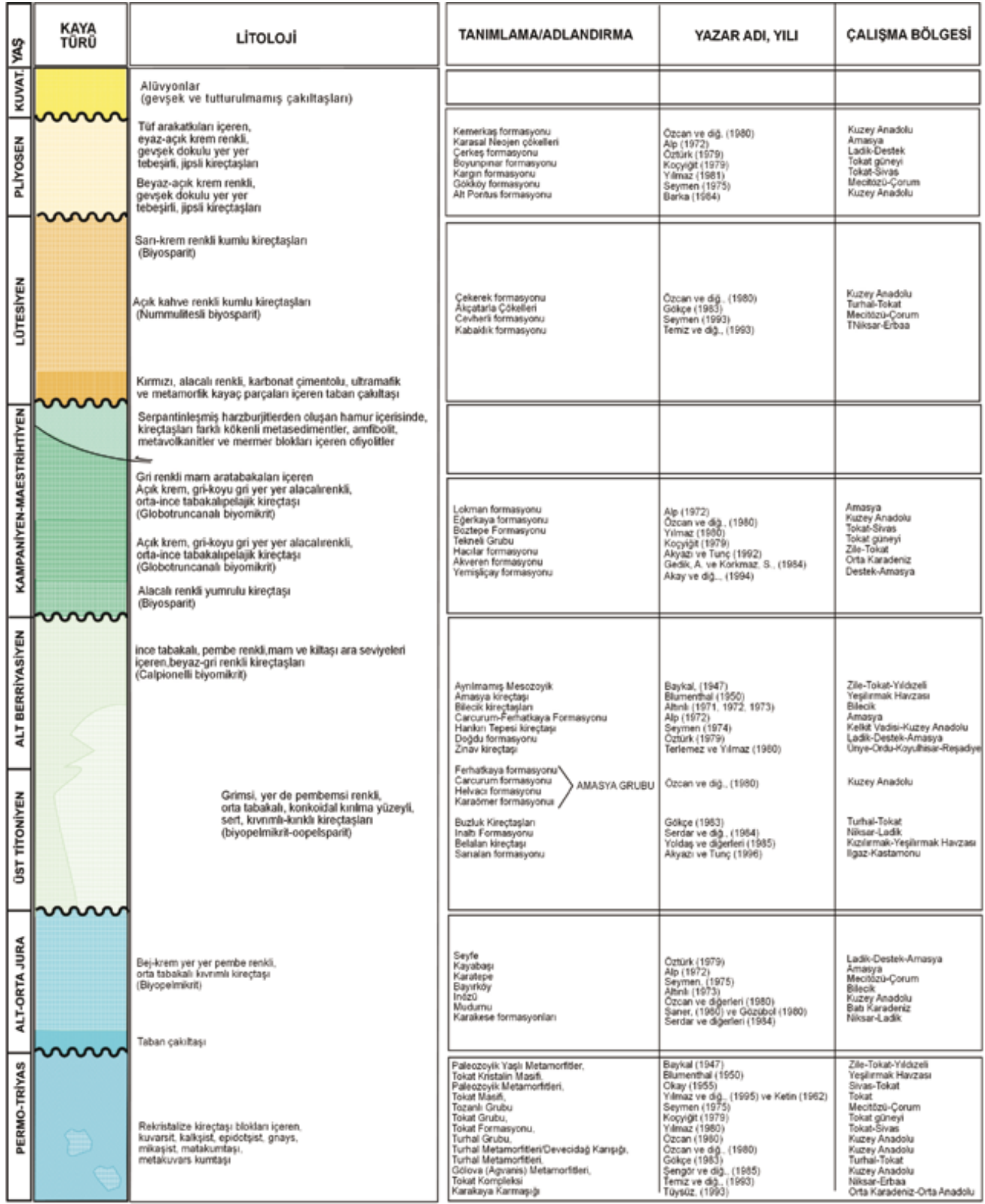

Şekil 14. İnceleme alanı ve yakın çevresinde tanımlanmış stratigrafik adlamaların karşılaştırması

Figure 14. The correlation of stratigraphic defination in the investigated area and vicinity 


\section{SONUÇLAR}

1. İnceleme alanından 9 adet ölçülü stratigrafi kesitialınmış, bunlardan Titonik fasiyeste gelişmiş, bol oranda Calpionel içeren 5 ölçülü stratigrafi kesitinde; sistematik olarak derlenmiş kayaç örnekleri üzerinede ayrıntılı paleontolojik ve biyostratigrafik çalışmalar yapılmış, toplam, 4 calpionel cinsi ve bu cinselere ait 9 tür saptanarak tanımlanmış ve sistematikleri yapılmıştır.

2. Geç Titoniyen-Erken Berriyasiyen yaşl1, titonik fasiyes ürünleri olan, calpionelli ve radiolarialı biyomikritik mikrobiyofasiyeste gelişmiş, ince tabakalı kireçtaşları üzerinde yapılan biyostratigrafik çalışmalarda Crassicollaria/Crassicollaria intermedia, Calpionella alpina, Calpionella elliptica, Calpionellopsis simplex-Calpionellopsis oblonga calpionel biyozonları saptanmıştır

3. Zile (Tokat) yöresinde istif alttan kısmen olmak üzere alttan ve üstten eksiklidir. Crassicollaria intermedia, zonu Crassicollaria intermedia (Durand Delga) ve Tintinnopsella carpathica (Murgeanui \& Filipescu) fosilleri gözlenemediğinden net olarak saptanamamış ve bu zon Crassicollaria zonu olarak tanımlanmıştır. Ayrıca Calpionella alpina ve Calpionella elliptica biyozonları da saptanmıştır.

4. Turhal (Tokat) yöresinde istif alttan tamam olup, üstten fosil bulgularında eksiklik vardır. Lorenziella hungarica Knauer \& Nagy gözlenemediğinden zon tanımı eksik fosille saptanmıştır. $\mathrm{Bu}$ yörede Crassicollaria intermedia,
Calpionella alpina, Calpionella elliptica, Calpionellopsis simplexCalpionellopsis oblonga biyozonları saptanarak tanımlanmıştır.

5. Pazar (Tokat) yöresinde istif in sı fasiyeste gelişmiş olduğu gözlenmiştir. $\mathrm{Bu}$ nedenle saptanan fosil formlariyla kuzeyde tanımlanan istifin yanal devamı olduğu düşünülmekla birlikte yaş bulgusu detay tanımlanamamış ve Üst Jura-Alt Kretase yaşı verilmiştir.

6. Çalışmalarda saptanarak tanımlanan calpionel biyozonlarının Roma Standart Zonlarıyla karşılaştırması yapılmış ve saptanan zonların zon sinırlarıyla, Roma Standart Zon sınırlarının önemli ölçüde uyuştuğu gözlenmiştir.

7. Torid Kuşağında yüzeyleyen Üst Jura-Alt Kretase yaşlı kireçtaşlarının genellikle portland fasiyeste gelişmiş olduğu ve Calpionel içermediği gözlenirken, Pontid kuşağında yüzeyleyen Üst Jura-Alt Kretase yaşlı kireçtaşlarının genellikle Batı Pontidlerde daha baskın olmak üzere Titonik fasiyeste geliştiği ve bol oranda Calpionel içerdiği gözlenmektedir.

8. Pontid kuşağında yüzeyleyen Üst JuraAlt Kretase yaşlı kireçtaşlarının çoğun olarak Titonik fasiyeste gelişmiş ince tabakalı mikritik kireçtaşlarından oluşmuş olmasına karşın, tamamının Calpionel içermediği ancak doğusundaki yüzleklere göre daha fazla Calpionel içerdiği gözlenmiştir. $\mathrm{Bu}$ durum Calpionellerin gerçek olmasa da yerel olarak provincializm gösterdiğine de işarettir.

9. Yapılan detaylı paleontolojik çalışmalar ile Calpionellerin yanısıra Globotruncana 
sp., Globotruncanita sp. ve Rosita sp. cinslerine ait 6 adet pelajik foraminifer türü saptanmış ve sistematik tanımlamaları yapılmıştır.

10. İnceleme alanında yapılan ayrintılı paleontolojik ve stratigrafik çalışmalarla desteklenen saha gözlemlerimize de dayanarak, bölge kuzeyi ve batısındaki istiflerin içerdikleri derin denizel formların varlığının yanısıra, güneydeki ve doğudaki istiflere göre daha sürekli bir yapı göstermelerinden yola çıkarak, kuzeyde ve batıda derin olan ve doğuya ve güneye doğru sığlaşan bir denizin varlığından söz edebiliriz.

11. Bölge temelinde yer alan sert dokulu karmaşı̆̆ın ve Jura-kretase yaşlı sert dokulu rekristalize kireçtaşlarının inceleme alanındaki rölyefleri oluşturduğu, rekristalize kireçtaşlarının bölgenin temelinde çok yaygın olan alüvyal örtü içerisinde yüzer durumdaki tepecikleri oluşturduğu gözlenmiştir.

12. Önceki çalışmalarda adlandırılan ve literatürde oldukça fazla karmaşaya neden olan formasyon tanımlamalarının tam olarak stratigrafik kurallara uymadığ litodem birimlerinin de litostratigrafik birimler gibi tanımlanarak adlandırıldığı gözlenmiştir. Ayrıca küçük bir coğrafya içerisinde birbirlerine çok yakın yüzeyleyen litofasiyesleri, biyofasiyesleri ve kronostratigrafik düzeyleri aynı birimlerin değişik çalışmalarda farklı adlamalarla tanımlandığı, sonuç olarak çok fazla formasyon adlaması olduğu gözlenmiştir (Şekil 13).

Yakın coğrafyada yüzeyleyen aynı birimlerin ayrı adlandırmalarla tanımlaması literatürde karmaşaya yol açtığı gibi, bu birimlerin bölgesel ölçekte diğer istiflerle deneştirilebilmesini de olanaksiz hale getirmektedir. $\mathrm{Bu}$ nedenle bu çalışmada literatürde karmaşaya yer açmamak için, yeni bir adlama/tanımlama yapmadığımız gibi tanımlanmış formasyon adlamalarını kullanmamanın da uygun olacağı kanısını taşımaktayız.

KATKI BELIRTME: Bu çalışmanın bir bölümü Cumhuriyet Üniversitesi Bilimsel Araştırma Projeleri Komisyonu tarafından sağlanan maddi destekle yapılmıştır.

EXTENDED SUMMARY: The different geological studies were carried out in the north of Anatolids which is located at the south of Pontid Tectonic belt on the Erzincan-Yozgat Ophiolit Belt. But, stratigraphic features of region have not yet realized.

The presences of base cover separation are established as all Pontid Tectonic Belt when stratigraphic units are investigated in the studied area that is located at the northwest of Tokat city. Upper Mesozoic cover units are one of cover units located uncormably on base units and are interesting in terms of fossil content and diversity. In this study, these units are dated as detail and stratigraphy of region is constructed according to these ages.

Detail paleontology and correlation of formations which are described different names in previous studies their are realized. These data may to be answer to confusion of formation defination and stratigraphic range and also is thought to provide significant results in terms of tectonostratigraphy 


\section{DEĞINIILEN BELGELER}

Akay, E. H., Herece, E. ve Ateş, Ş. (1994) Destek (Orta Pontidler) dolayında Akgöl Formasyonunun yaş bulgusu. MTA Dergisi 116, 105-107.

Aktimur, T. H., Ateş, Ş., Yurdakul, M. E., Tekirli, M. E. ve Keçer, M.(1992) Niksar-Erbaa ve Destek dolayının jeolojisi. MTA Dergisi 114, 25-36,

Akyazı, M. (1991) Zile (Tokat) Yöresinin Jeolojik ve Paleontolojik Özellikleri. C.Ü. Müh. Fak. Fen Bilimleri Enst., Jeo. Müh. Böl., Yüksek Lisans Tezi (Yayımlanmamış), 93. s., Sivas.

Akyazı, M. ve Tunç, M. (1992) Zile (Tokat) Yöresinin Stratigrafisi. TJK Bülteni, C. 35/2, 36-42.

Akyazı, M., Toprak, Ö., Erdoğan. T., Karabaşoğlu, A. ve Ursavaş, T, Ş. (2001) Bilecik Yöresinin Mesozoyik Stratigrafisi. C.Ü. Müh. Fak. Dergisi, seri A., Yerbilimleri C.18, S.1, .27-46.

Alp, D. (1972) Amasya yöresinin jeolojisi. İ.Ü. Fen Fakültesi Monografileri, Sayı; 22, $10 \mathrm{~s}$.

Altınlı, I.E. ve Saner, S.(1971) Bilecik yakın dolayının jeoloji incelemesi. İ.Ü.Fen. Fak. Mec. Seri B,C.36,S.1-2,1-21.

Altınlı, İ.E. ve Yetiş, C. (1972) Bayırköy-Osmaneli (Bilecik) alanının jeolojik incelenmesi. İ.Ü.Fen Fak. Mec. C.37, s.1-2, 1-17.

Altınlı, 1.E. (1973) Orta Sakarya Jeolojisi: Cumhuriyetin 50. yılı Yerbilimleri Kongresi, MTA Yayınları, 159-191, Ankara.

Atalay, Z. (2001) Amasya Yöresi'ndeki Linyitli Çeltek Formasyonunun Stratigrafisi, Fasiyes ve Çökelme Ortamı Özellikleri. Türkiye Jeoloji Bülteni Cilt 44, Sayı 2, 1-22.

Barka, A. (1984) Kuzey Anadolu fay zonundaki bazı Neojen Kuvaterner havzalarının jeolojisi ve tektonik evrimi. Türkiye Jeoloji Kurumu, Ketin Sempozyumu, Ankara, s. 209-227.

Baykal, F. (1947) Zile -Tokat- Yıldızeli bölgesinin jeolojisi. İ.Ü. Fen Fakültesi Mecmuası, Seri B, c.XII, sayı: 3, s.19.

Blumenthal, M. (1950) Beitrage zur géologie der landschaften am miitelcren und unteren Yeşilırmak. MTA, yayınları seri. D. No. 4, $183 \mathrm{~s}$.

Gedik, A., Ercan, T. ve Korkmaz, S, (1983) Orta Karadeniz (SamsunSinop) Havzasının Jeolojisi ve Volkanik Kayaçların Petrolojisi. MTA Dergisi, 99/100, 34-51.

Gökçe, A. (1983) Turhal Antimon Yataklarının Maden Jeolojisi. H, Ü. Doktora Tezi, (Yayımlanmamış).

Görür, N., Şengör, A. M. C, Akkök, R. ve Yılmaz, Y. (1983) Pontidlerde Neo-Tetis'in kuzey kolunun açılmasına ilişkin sedimantolojik veriler. TJK Bülteni, 26, 11-20 s.

Gözübol, A. M. (1980) Mudurnu - Dokurcun Abant (Bolu ili) alanının jeoloji incelemesi ve Kuzey Anadolu Yarılımının yapısal özellikleri. İst. Üniv. Fen Fak. Mec. Seri B, c.45, s. 9-34.
Koçyiğit, A. (1979) Tekneli bölgesinin (Tokat güneyi) tektonik özelliği. Tübitak Proje no TBAG-262,63 s.

Minaz, M. (1984) Tokat-Zile-İ.T. 10564 ruhsat nolu linyit sahasına ait fizibilite raporu. MTA. Enst. Rapor no 40200/1, 16 s. (Yayınlanmamış).

Okay, A. C. (1955) Sivas ile Tokat arasındaki bölgenin jeoloetüdü: î. Ü. Fen Fak. Mecmuası, Seri B, Cilt XX, Sayı: 2,95-108.

Öztürk, A. (1979) Ladik-Destek yöresinin stratigrafisi: Türkiye jeoloji Kurumu Bülteni, 22,27-34.

Özcan, A., Erkan, A., Keskin, A,, Keskin, E., Oral, A., Özer, S., Sümengen, M. ve Tekeli, O. (1980) Kuzey Anadolu Fayı ile Kırşehir Masifi arasının temel jeolojisi: MTA Enst. Rapor No: 6722, 139 s. (yayımlanmamış).

Saner, S. (1980) Batı Pontidlerin ve Komşu Havzaların Oluşumlarınınlevha Tektoniği Kuramıyla Açıklanması, Kuzeybatı Türkiye: MTA Dergisi, 93/94, 1 -19.

Serdar, H.S., Yarman, M. Kazdal, R.A. ve Namoğlu, C. (1984) Samsun-Ladik-Niksar-Terme (Kuzey Anadolu Fay Zonu) jeolojik etüdü ve petrol olanakları: TPAO Rap. No. 2650 (yayımlanmamış).

Seymen, İ. (1975) Kelkit vadisi kesiminde Kuzey Anadolu fay zonunun tektonik özelliği, Doktora Tezi, İ.T.Ü. Maden Fakültesi Yayınları $192 \mathrm{~s}$.

Seymen, İ. (1993) Mecitözü dolayının stratigrafik gelişimi, Suat Erk Jeoloji Simpozyumu Bildirileri, A.Ü. Fen Fak. Jeoloji Müh. Böl., 129-141.

Şengör, A.M.C., Yılmaz, Y., Sungurlu, O. (1985) Tectonics of the Mediterranean Cimmerides, nature and evolution of the western termination of Paleo-Tethys. In: Dixon, J.E. ve Robertson, A.H.F. (eds), The Geological Evolution of the Eastern Mediterranean. Geological Society, London, Special Publications, 17, 77-112.

Tatar, Y. (1983) Yıldızeli Subaşı Köyü yöresinde tektonik incelemeler. TJK Bülteni, 4, 3-15.

Temiz, H, Tatar, O. ve Tutkun, Z. (1993) Niksar-Erbaa havzaları paleotektonık dönem kayalarının stratigrafisi. A. Suat Erk Jeoloji Sempozyumu Bildirileri, A. Ü. Fen Fak. Jeoloji Müh. Böl. 157-170.

Terlemez, H.1.Ç. ve Yılmaz, A. (1980) Ünye, Ordu, Koyulhisar, Reşadiye arasında kalan yörenin stratigrafisi. Türkiye Jeo. Bült, 23/2, 179-193, Ankara.

Tetiker, S., Yalçın, H. ve Bozkaya, Ö. (2009) Karakaya karmaşı̆̆ı (Tokat yöresi) birimlerinin düşük Dereceli metamorfizması. 14. Ulusal Kil Sempozyumu Bildiriler Kitabı, s.155-173, KTÜ, Trabzon-Türkiye

Toker, V. (1977) Haymana Yöresinin (SW Ankara) Planktonik Foraminifera ve Nannoplankton'ların Biyostratigrafik incelenmesi; (Doçentlik tezi), s. 59-92, Ankara. 
Tunç, M. (1991) Aktaş (Kızılcahamam) Yöresindeki pelajik kireçtaşlarının biostratigrafisi. TJK Bült. 34/2, 27-43.

Tunç, M. (1992a) Olur (Erzurum) yöresindeki Üst Jura-Alt Kretase yaşlı kireçtaşlarının Biyostratigrafisi. T.J.K Bült. 35/1, 121-130.

Tunç, M. (1992b) Description of a new species of Crassicollarla from surrounding olur (Erzurum-Turkey). Revue de paleobiologle, 11/2, pp. 463-468, Geneve

Tunç, M. ve Akyazı, M. (2001) Calpioneller, 64 sayfa MTA Yayınları eğitim serisi No:35, Ankara.

Tüysüz, O. (1993) Karadeniz'den Orta Anadolu'ya bir jeotravers, Kuzey Neo-tetisin tektonik evrimi. TPJD Bült. C.5/1,s. 1-33.

Tüysüz, O. (1996) Amasya ve çevresinin jeolojisi. Türkiye 11. Petrol Kongresi, Bildiriler, Türkiye Petrol Jeologları Derneği/ TMMOB Petrol Mühendisleri Odası/TMMOB Jeofizik Mühendisleri Odası, s. 32-48.

Üstüntaş, A. ve İnceöz, M. (1999) Zile (Tokat) batısında Uzunköy çevresinin stratigrafisi; Türkiye Jeoloji Bülteni Cilt. 42, Say1 1,69-83.

Yalçın Erik, N. ve Ay, F. (2010) Tersiyer yaşlı Artova ve Zile kömürlerinin (Tokat) organik jeokimyasal özellikleri ve hidrokarbon türetim potansiyelleri H. Ü.Yerbilimleri Dergisi, Sayı: 31-3, s. 169-190.

Yılmaz, A. (1980) Tokat ile Sivas arasındaki bölede ofiyrj îitlerin kökeni, içyapısı ve diğer bilimlerle ilişskisi A.Ü, Fen Fakültesi Jeolojisi Kürsüsü, doktora tezi, 136 s. (yayınlanmamış).
Yılmaz, A. (1981) Tokat ile Sivas arasındaki bölgede ofiyolitli karışı̆̆ın iç yapısı ve yerleşme yaşı: TJK. Bült. 24/1,s.3138.

Yılmaz, Y., Yiğitbaş, E., Yıldırım, M., Genç, Ş. C, Elmas, A., Gürer, Ö. F., Bozcu, M., Gürpınar, O. ve Serdar, H. S. (1995) Geology and development of the Tokat Massif, Second International Turkish geology workshop, Abstracts, Cumhuriyet Univ., Müh. Fak., Jeol. Müh. Böl., 117.

Yoldaş, R., Keskin, B., Korkmaz, S., Didik, S.. Kalkan, 1., Ağrıdağ, D.S. ve Besbelli, B. (1985) Samsun ve dolayı (KızılırmakYeşilırmak arasındaki bölgenin) jeolojisi ve petrol olanakları: MTA Rap., 8130 (yayımlanmamış), Ankara.

\begin{tabular}{|c|c|}
\hline Makale Geliş Tarihi & : 6 Ekim 2013 \\
\hline Kabul Tarihi & : 12 Kasim 2013 \\
\hline Received & $: \quad 6$ October 2013 \\
\hline
\end{tabular}

